\title{
Avaliação da imunidade humoral e celular em cães naturalmente infectados com Leishmania (L.) chagasi e sua correlação com a transmissibilidade para o vetor
}

Tese apresentada ao Programa de Pós-Graduação em Patologia Experimental e Comparada da Faculdade de Medicina Veterinária e Zootecnia da Universidade de São Paulo para obtenção do título de Doutor em Ciências

Departamento:

Patologia

Área de concentração:

Patologia Experimental e Comparada

Orientador:

Profa. Dra. Márcia Dalastra Laurenti 
Folha

Resumo

Abstract
Parágrafo

1

1
Linha

3

3
Onde se lê

[título em português]

[título em inglês]
Leia-se

[Evaluation of humoral and cellular immunity in dogs naturally infected with Leishmania (L.) chagasi and its correlation to the transmissibility to the vector] [Avaliação da imunidade humoral e celular em cães naturalmente infectados com Leishmania $(L)$ chagasi e sua correlação com a transmissibilidade para o vetor] 
Autorizo a reprodução parcial ou total desta obra, para fins acadêmicos, desde que citada a fonte.

DADOS INTERNACIONAIS DE CATALOGAÇÃO-NA-PUBLICAÇÃO

(Biblioteca Virginie Buff D’Ápice da Faculdade de Medicina Veterinária e Zootecnia da Universidade de São Paulo)

T.2009 Larangeira, Daniela Farias

FMVZ Avaliação da imunidade humoral e celular em cães naturalmente infectados com Leishmania (L.) chagasi e sua correlação com a transmissibilidade para o vetor / Daniela Farias Larangeira. - São Paulo : D. F. Larangeira, 2008.

$79 \mathrm{f}$ : : il.

Tese (doutorado) - Universidade de São Paulo. Faculdade de Medicina Veterinária e Zootecnia. Departamento de Patologia, 2008.

Programa de Pós-Graduação: Patologia Experimental e Comparada.

Área de concentração: Patologia Experimental e Comparada.

Orientador: Profa. Dra. Márcia Dalastra Laurenti.

1. Leishmaniose canina. 2. Resposta imune humoral. 3. Resposta imune celular. 4. Xenodiagnóstico. 5. Leishmania (L.) chagasi. I. Título. 
Folha de Avaliação

Nome: Larangeira, Daniela Farias

Título: Avaliação da imunidade humoral e celular em cães naturalmente infectados com Leishmania (L.) chagasi e sua correlação com a transmissibilidade para o vetor

Tese apresentada ao Programa de Pós-Graduação em Patologia Experimental e Comparada da Faculdade de Medicina Veterinária e Zootecnia da Universidade de São Paulo para obtenção do título de Doutor em Ciências

Data

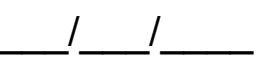

\section{Banca Examinadora}

Prof.Dr. Instituição

Assinatura Julgamento

Prof.Dr. Instituição

Assinatura Julgamento

Prof.Dr. Instituição

Assinatura: Julgamento

Prof.Dr Instituição

Assinatura: Julgamento

Prof.Dr. Instituição

Assinatura: Julgamento 


\section{DEDICATÓRIA}

Aos cães,

Dedico este trabalho a todos os cães sacrificados em Centros de Controle de Zoonoses que mesmo em seus últimos momentos conservam um olhar terno.

Sonho com o dia que essa matança termine! 


\section{AGRADECIMENTOS}

A Profa. Dra. Márcia Dalastra Laurenti pela excelente orientação, incentivo e entusiasmo.

Ao Prof. Dr. Carlos E. P. Corbett e a Dra. Claudia M. C. Gomes pelo acolhimento carinhoso quando cheguei ao laboratório.

Aos estudantes Rafael, Thaise, Michelli, Carol e Tadeu, sem vocês nada seria possível.

Aos amigos do LIM-50, fundamentais em todos os momentos deste trabalho. Em especial a Sra. Lia Negrão por todo o apoio.

Aos professores Stella Barrouin e Paulo Aguiar, meus eternos orientadores e amigos.

A(s) Profa(s). Dra(s). Mary Feitosa, Cecília Luvizotto, Cáris Nunes e aos alunos de Pós-Graduação Cláudio Rossi e Fabiana Ikeda-Garcia por todo o suporte durante a realização do estudo no Campus da UNESP de Araçatuba (SP).

Aos Drs. Paulo Pimenta e Nágila Secundino pela colaboração na execução do xenodiagnóstico. 
A Faculdade de Medicina Veterinária e Zootecnia da USP, ao Laboratório de Patologia de Moléstias Infecciosas do Depto. Patologia da Faculdade de Medicina da USP, a Faculdade de Medicina Veterinária da UNESP-Araçatuba, ao Laboratório de Entomologia Médica, Centro de Pesquisas René Rachou-FIOCRUZ e ao Centro de Controle de Zoonoses do município de Araçatuba (SP) pela excelente estrutura disponibilizada para a execução deste projeto. E a todas as pessoas responsáveis por sua organização.

Ao apoio financeiro da FAPESP, processo número 2004/07965-2, que viabilizou todo o desenvolvimento deste projeto.

A minha família, que mesmo não concordando com milhas escolhas acabam as apoiando.

Aos meus amigos sempre presentes em minha vida. Em especial a Joana que me ajudou nos piores momentos.

Ao Marcel por existir e me fazer experimentar o maior Amor do mundo.

E por fim aos animais que são meu porto seguro sempre que há tempestades. 


\section{SUMÁRIO}

1 INTRODUÇÃO

1.1 Interação parasito, vetor e resposta imune do hospedeiro................................04

1.2 Regulação da resposta imune na leishmaniose visceral................................06

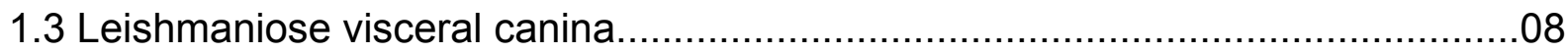

1.4 Diagnóstico da leishmaniose visceral canina...........................................11

1.5 Tratamento da leishmaniose visceral canina.............................................. 13

1.6 Patogênese da leishmaniose visceral canina..........................................14

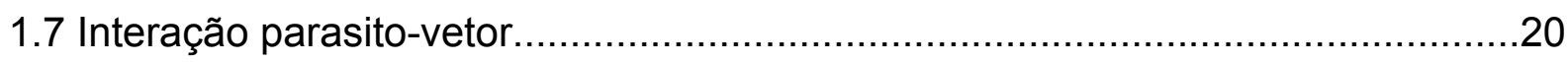

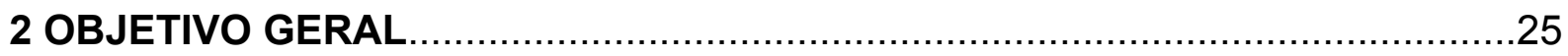

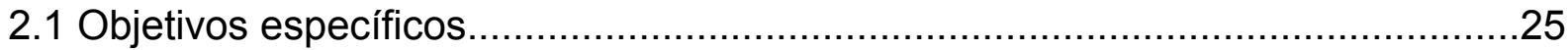

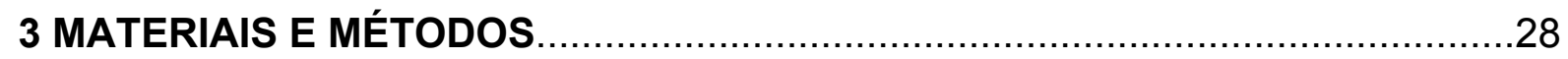

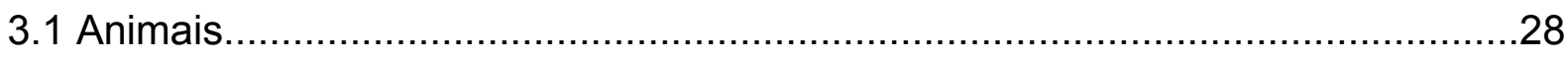

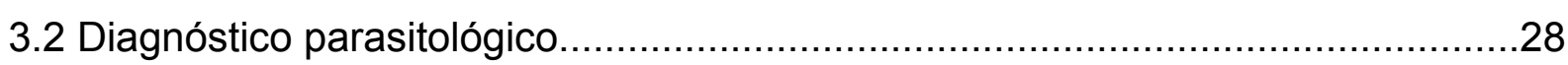

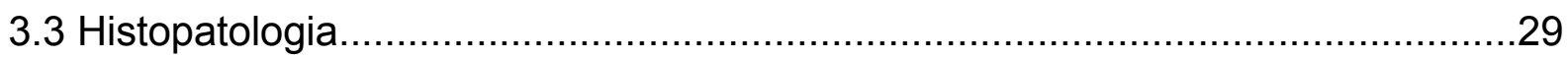

3.4 Immunoistoquímica em tecido parafinado para detecção de parasitos, macrófagos e células CD3+ em fragmentos de baço, linfonodo e pele de cão. 29

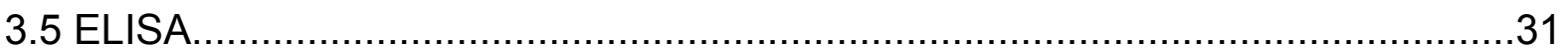

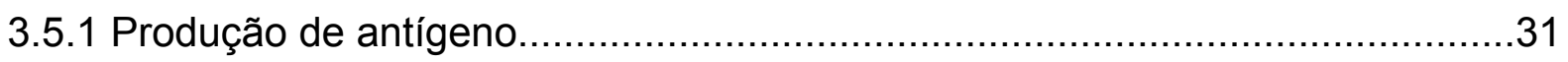

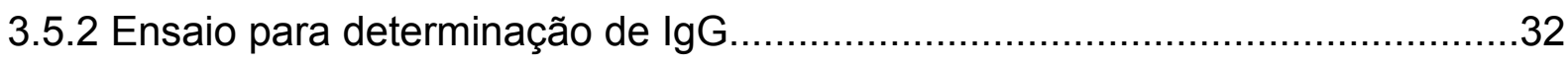

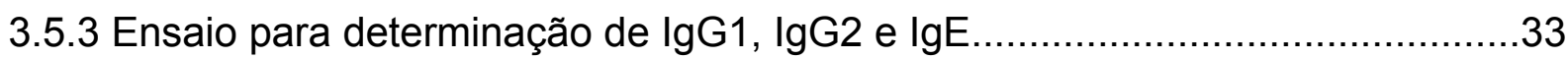

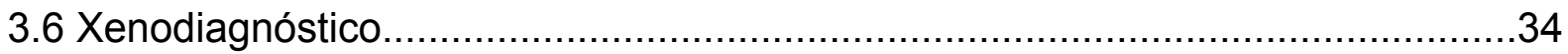

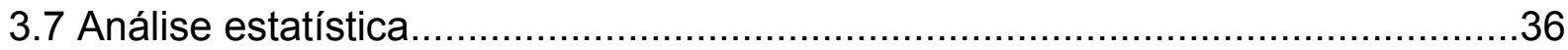

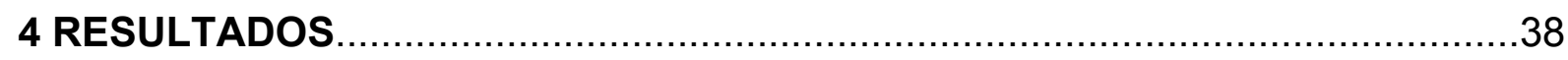

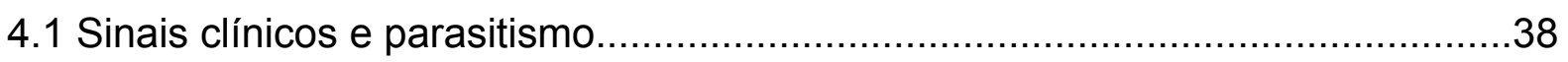

4.2 Alterações histológicas e parasitismo........................................................41

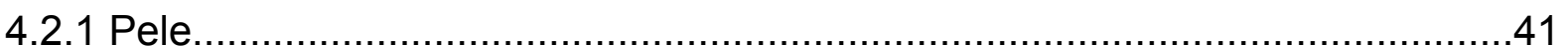

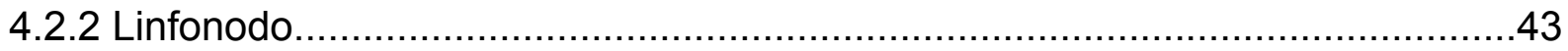




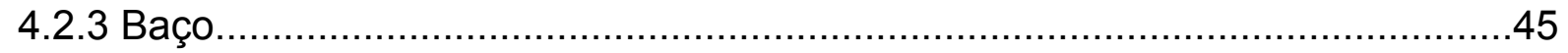

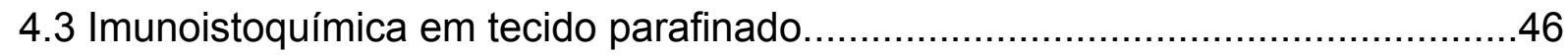

4.4 Correlação entre a imunomarcação de macrófagos e linfócitos com a carga

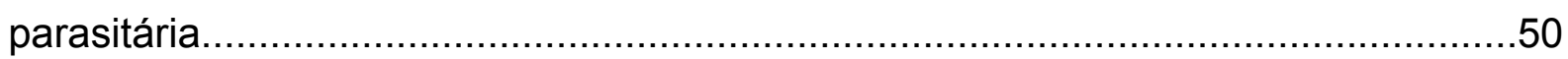

4.5 Deteç̧ão de classes e suclasses de imunoglobulinas......................................51

4.6 Correlação entre parasitismo e classes e subclasses de

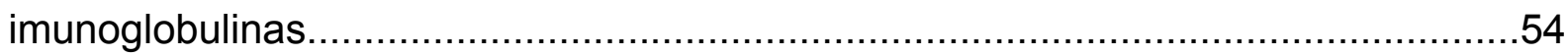

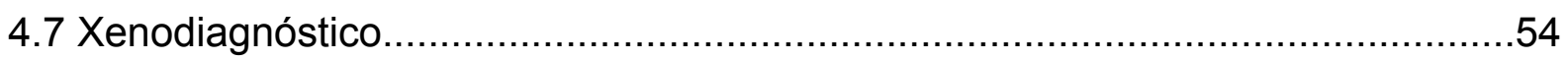

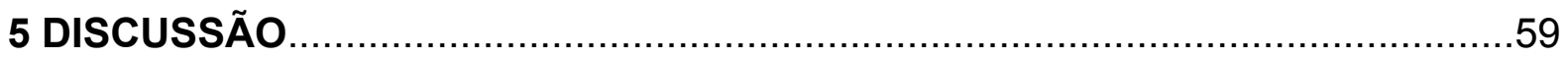

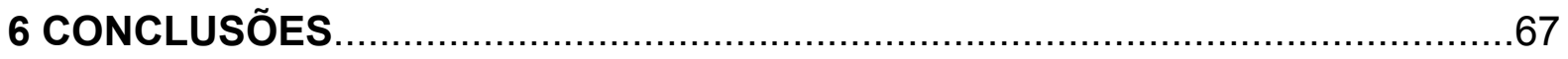

REFERÊNCIAS 


\section{RESUMO}

LARANGEIRA, D. F. Avaliação da imunidade humoral e celular em cães naturalmente infectados com Leishmania (L.) chagasi e sua correlação com a transmissibilidade para o vetor. [título em português]. 2008. 79f. Tese (Doutorado em Ciências) - Faculdade de Medicina Veterinária e Zootecnia, Universidade de São Paulo, São Paulo, 2008.

Este estudo avaliou a imunidade humoral e celular em cães naturalmente infectados com L. (L.) chagasi correlacionando com a transmissibilidade para o vetor. Soros e biópsias de baço, linfonodo e pele foram coletados de 120 cães provenientes do Centro de Controle de Zoonoses do município de Araçatuba, São Paulo, Brasil. Os soros foram processados por ELISA para detecção de $\lg$, $\lg _{1}$, $\operatorname{lgG}_{2}$ e $\operatorname{lgE}$; e as biópsias foram processadas por técnicas histológicas usuais coradas pelo HE e imunoistoquímica para a detecção de parasito, macrófago e células T CD3. De acordo com os sinais clínicos, 65/120 (54\%) cães foram classificados como sintomáticos e 55/120 (46\%) como assintomáticos. O diagnóstico parasitológico foi confirmado em $71 \%$ dos sintomáticos e em $40 \%$ dos assintomáticos. A correlação dos sinais clínicos com parasitismo mostrou que a carga parasitária estava diretamente associada com cães sintomáticos $(p<0.05)$. Em relação aos anticorpos específicos anti-L.(L.)chagasi, cães de área endêmica com diagnóstico parasitológico positivo mostraram maiores níveis de lgG total comparado com ambos os controles $(p<0.05)$, sem diferença entre cães sintomáticos e assintomáticos. $\operatorname{lgG}_{1}$ esteve presente em baixos níveis e foi mais intensa no grupo sintomático parasito-positivo $(p<0.05)$. Níveis mais elevados foram observados para $\operatorname{lgG}_{2}$ em cães de área endêmica $(p<0.05)$, mas sem correlação com o parasitismo e sinais clínicos. IgE também esteve presente em baixos níveis, mas mostrou diferenças entre cães de área endêmica e cães de área não endêmica; e cães com diagnóstico parasitológico positivo mostrou níveis mais elevados que cães com diagnóstico parasitológico negativo $(p<0.05)$. Histopatologicamente, linfonodos mostraram hiperplasia e hipertrofia de macrófagos na área medular e em muitos casos linfadenite granulomatosa. Na polpa branca do baço, hiperplasia folicular foi observada; e a polpa vermelha mostrou granulomas. As lesões de pele foram caracterizadas por infiltrado inflamatório crônico na derme formado por macrófagos, linfócitos e plasmócitos; variando de discreto a intenso, assim como de focal a difuso. Foi evidente a presença de granulomas epitelióides 
na pele de alguns animais. Imunoistoquímica mostrou presença de células marcadas pelo anticorpo anti-macrófago e anti-CD3 em 100\% dos baços e linfonodos variando de intensidade entre discreto e intenso. Na pele, macrófagos foram positivos em $90 \%$ e células CD3 em 39\% dos casos. Houve associação direta entre baixa expressão de células CD3 e alto parasitismo na pele. Animais assintomáticos mostraram baixa expressão de macrófagos junto com baixo parasitismo na pele. Em relação ao xenodiagnóstico, no $4^{\circ}$ dia depois da alimentação, as fêmeas dos vetores foram dissecadas e examinadas para observação de parasitos no intestino. Formas promastigotas foram observadas em $27 \%$ das fêmeas que se alimentaram em cães sintomáticos e em $42 \%$ das fêmeas que se alimentaram em cães assintomáticos. A técnica da PCR foi também utilizada para avaliar as fêmeas positivas depois do xenodiagnóstico. DNA de Leishmania foi detectado em $24 \%$ das fêmeas que se alimentaram em cães sintomáticos e em $34 \%$ das fêmeas que se alimentaram em cães assintomáticos. Os dados mostraram que a imunidade humoral e celular não teve correlação direta com as formas clínicas de leishmaniose canina. A alta porcentagem de vetores infectados na alimentação em cães assintomáticos mostra a importância destes animais na transmissibilidade para o vetor.

Palavras-chave: Leishmaniose canina. Resposta immune humoral. Resposta imune celular. Xenodiagnóstico. Leishmania (Leishmania) chagasi 


\section{ABSTRACT}

LARANGEIRA, D. F. Evaluation of humoral and cellular immunity in dogs naturally infected with Leishmania (L.) chagasi and its correlation to the transmissibility to the vector. [título em inglês]. 2008. 79f. Tese (Doutorado em Ciências) - Faculdade de Medicina Veterinária e Zootecnia, Universidade de São Paulo, São Paulo, 2008.

These studies evaluate humoral and cellular immunity in dogs naturally infected with L. (L.) chagasi correlating to the transmissibility to the vector. Serum and biopsy from spleen, lymph node and skin were collected from 120 dogs referred to the Center of Zoonosis Control of Araçatuba city, São Paulo, Brazil. The sera were processed by ELISA for $\operatorname{lgG}, \operatorname{lgG}_{1}, \lg _{2}$ and $\lg E$ detection; and the biopsies were processed usual histological techniques stained by $\mathrm{HE}$ and immunohistochemistry for parasite, macrophage and T CD3 cells detection. According to the clinical signs, $65 / 120(54 \%)$ dogs were classified as symptomatic and $55 / 120(46 \%)$ as asymptomatic. Parasitological diagnosis was confirmed in $71 \%$ of symptomatic and in $40 \%$ of asymptomatic dogs. The correlation of clinical signs and parasitism showed that parasite burden was directly associated with symptomatic dogs $(p<0.05)$. Concerning to L.(L.)chagasi-specific antibodies, dogs from the endemic area with positive parasitological diagnosis showed high levels of total IgG compared to both controls $(p<0.05)$, without difference between symptomatic and asymptomatic dogs. $\operatorname{lgG}_{1}$ was present at low levels and was more intense in the parasite-positive symptomatic group $(p<0.05)$. More elevated levels were observed for $\operatorname{lgG}_{2}$ in dogs from endemic area $(p<0.05)$, but with no correlation to parasitism and clinical signs. IgE was also present at low levels, but showed differences between dogs from non-endemic and endemic areas; and dogs with positive parasitological diagnosis showed higher levels than dogs with negative parasitological diagnosis $(p<0.05)$. Histopathologically, lymph nodes showed macrophage hyperplasia and hypertrophy in the medullary area and in many cases granulomatous lymphadenitis. In the white pulp of the spleen, follicular hyperplasia was observed; and the red pulp showed granulomas. The skin lesions were characterized by dermal chronic inflammatory infiltrate formed by macrophages, lymphocytes and plasma cells; it varied between descreet to intense, as well as focal to diffuse. The epithelioid granulomas were evident in the skin of some animals. Immunohistochemistry showed presence of labeled cells by anti- 
macrophage and anti-CD3+ antibodies in 100\% of spleen and lymph nodes varying the intensity between mild to intense. Macrophage was positive in $90 \%$ of the skin and CD3 cells in 39\%. There was a direct association between lower CD3 cells expression and higher parasite burden in the skin. Asymptomatic animals showed lower macrophage expression together with lower parasitism in the skin. Concerning to the xenodiagnosis, on the $4^{\text {th }}$ day after the blood meal, female flies were dissected and examined for visible parasites in the gut. Promastigotes forms were observed in $27 \%$ of female which fed in symptomatic dogs and in $42 \%$ of female which fed in asymptomatic dogs. PCR technique was also used to evaluate the positive females after the xenodiagnosis. Leishmania DNA was detected in $24 \%$ of female which fed in symptomatic dogs and in $34 \%$ of female which fed in asymptomatic dogs. The data showed that the humoral and cellular immune response not has direct correlation to the clinical form of canine leishmaniasis. The high percentage of sand flies female infected by feeding in the asymptomatic dogs show the importance these animals on the parasite transmissibility to the vector.

Key words: Canine leishmaniasis. Humoral immune response. Cellular immune response. Xenodiagnosis. Leishmania (Leishmania) chagasi 


\section{INTRODUÇÃO}

A leishmaniose visceral (LV) é uma parasitose de caráter zoonótico, sendo apontada como uma das doenças mais importantes do ponto de vista da saúde pública em cerca de 80 países da Ásia, África e América Latina (ASHFORD et al., 1992). Estima-se que em todo mundo existam, aproximadamente, 12 milhões de pessoas infectadas e outras 350 milhões vivendo em áreas de risco. Nas Américas Central e do Sul a leishmaniose caracteriza-se por apresentar aspectos distintos das do Velho Mundo quanto a sua etiologia e epidemiologia (GRIMALDI; TESH 1993). A Leishmania (Leishmania) chagasi é um protozoário pertencente ao chamado complexo Leishmania donovani, no qual estão incluídas as três principais espécies causadoras da leishmaniose visceral, L. (L.) chagasi, L. (L.) infantum e L. (L.) donovani (BABARÓ, 1996; SHERLOCK, 1996a). De acordo com a taxonomia proposta por Lainson e Shaw (1979), este parasito pertence ao gênero Leishmania, família TRYPANOSOMATIDAE, sub-ordem TRYPANOSOMATINA, ordem KINETOPLASTIDA e classe ZOOMASTIGOPHOREA que pode infectar cães e outras espécies vertebradas, incluindo o homem (BADARÓ et al., 1996). Há evidências de que a $L$. (L.) chagasi possa ser a $L$. (L.) infantum, trazida para o Novo Mundo por imigrantes dos países mediterrâneos (MAURÍCIO et al., 2000).

O gênero Leishmania possui formas características de parasitismo no vertebrado e no inseto vetor. No mamífero, o parasito apresenta-se sob forma aflagelada, denominada amastigota, que se multiplica no interior das células do sistema mononuclear fagocitário por divisão binária. Após serem ingeridas pelas fêmeas de flebotomíneo, por ocasião do repasto sanguíneo, estas formas transformam-se em formas flageladas, denominadas promastigotas, no tubo 
digestivo do inseto e, após quatro dias, já podem ser transmitidas a um novo hospedeiro (SHERLOCK, 1996b; BOGDAN; ROLLINGHOFF 1998).

A doença canina é considerada, do ponto de vista epidemiológico mais importante que a doença humana, pois, além de ser mais prevalente, apresenta grande contingente de animais assintomáticos albergando parasitas na derme, com potencial para transmitir a doença (MARZOCHI et al., 1985). Os caninos domésticos são responsabilizados pela dispersão da doença a partir de focos enzoóticos. A doença no cão geralmente precede a ocorrência da doença no homem, sendo que ambas coexistem em todos os focos conhecidos (BADARÓ et al., 1996).

A emergência da leishmaniose como um problema de saúde pública tem ocorrido devido a vários fatores, dentre eles, principalmente, estão as alterações ecológicas e demográficas decorrentes das destruições de florestas primárias, acompanhadas pelo rápido crescimento populacional e assentamentos de comunidades nas periferias de cidades, o que leva a uma mudança na ecologia dos flebotomíneos vetores. Os novos migrantes usualmente trazem consigo seus cães, galinhas e porcos os quais mantêm próximos às suas casas, elevando as chances de contaminação (TESH et al., 1995). Em conseqüência, a leishmaniose começou recentemente a aparecer em áreas suburbanas de várias cidades tais como Fortaleza, Natal, Teresina, São Luiz, Santarém, Belo Horizonte e Rio de Janeiro (COSTA et al., 1990; MONTEIRO et al., 1994; SANTA ROSA, 1997).

Até 1998 não havia referência de casos autócnes de leishmaniose visceral canina ou humana no estado de São Paulo. Em maio de 1998, foi descrito um foco de leishmaniose visceral canina (LCV) no município de Araçatuba, localizado na região noroeste de São Paulo (LUVIZOTTO et al.,1999). No ano seguinte houve 17 casos humanos no município e dois em Birigui, município vizinho com total de cinco 
óbitos. O número de casos humanos e municípios atingidos têm aumentado, em 2003 foram 157 casos com 23 óbitos em 19 municípios. Entre os municípios atingidos está Bauru, localizado aproximadamente a aproximadamente $300 \mathrm{~km}$ da cidade de São Paulo que não possuía casos humanos da doença até 2002, porém levantamento soro-epidemiológico na população canina já havia detectado um percentual de 5,8 de positividade. No ano seguinte foram notificados 10 casos humanos. Estes dados demonstram a importância da doença no Estado e a necessidade de pesquisas que possam auxiliar no controle da doença (Divisão de Zoonoses-CVE/SP).

No Brasil, o Programa de Controle de Leishmaniose Visceral (PCVL) da Fundação Nacional da Saúde, consiste em ações tomadas contra o reservatório, que são: a identificação, o diagnóstico imediato e a eliminação destes animais, visando reduzir as fontes de infecção para os flebótomos; o rápido diagnóstico e tratamento dos indivíduos doentes; e a borrifação de piretróides nos bairros onde há casos humanos objetivando o controle de vetores. Nas áreas onde ocorre um índice de soro-positividade canina até $1 \%$, recomenda-se uma vigilância epidemiológica e, em regiões onde este índice for maior que $1 \%$, está indicada a eliminação de cães positivos e estudos entomo-epidemiológicos para determinar a abrangência do problema (MONTEIRO et al., 1994). Porém diversos estudos têm questionado a efetividade destas ações, pois o impacto na transmissão humana é limitado e possui alto custo (TESH, 1995; PARANHOS-SILVA et al., 1996). A produção de uma vacina para leishmaniose visceral canina constitui um consenso, entre os pesquisadores, para o controle da LV (REITHINGER; DAVIES, 2002; MORENO; ALVAR, 2002). Diversas pesquisas estão sendo realizadas, já existindo uma vacina sendo comercializada, porém há questionamentos sobre a real eficácia desta no controle 
da transmissão da doença. O cão vacinado pode apresentar uma resistência ao desenvolvimento da doença, porém permanecer infectivo para o flebótomo vetor. Por isso estudos visando o conhecimento da resposta imunopatológica do cão infectado e técnicas que permitam diferenciar animais transmissores de não trasmissores do parasito para o vetor são de grande valia para o controle desta zoonose (ALVAR et al., 1994; GUARGA et al., 2002).

\subsection{Interação parasito, vetor e resposta imune do hospedeiro}

Os protozoários desenvolveram estratégias complexas de evasão ao sistema imune do hospedeiro, provavelmente utilizadas durante todo o processo de infecção, promovendo a sua perpetuação no organismo. Em relação à Leishmania, evidências clínicas e experimentais indicam que, além de fatores presentes no parasito e no hospedeiro, a saliva do vetor influencia a evolução da doença (LIMA; TITUS, 1996). As falhas dos hospedeiros vertebrados em controlarem a infecção podem estar relacionadas a dois fatores principais: a habilidade da Leishmania em resistir às ações microbicidas dos macrófagos ativados e a inibição da resposta imune celular do hospedeiro (GRIMALDI; TESH, 1993).

A forma promastigota metacíclica da Leishmania, encontrada na probócida do flebotomíneo, é resistente a lise pelo sistema do complemento (NORONHA et al., 1998). Isto ocorre, possivelmente, devido à presença de glicofosfoglicano (LPG) na membrana celular do parasito e da LPK-1 (proteína cinase de Leishmania) (BOGDAN; ROLLINGHOFF, 1998). Estas moléculas não permitem a ligação adequada do complexo de ataque à membrana (MAC) ao parasito, impossibilitando sua lise pelo complemento (BOGDAN et al., 1996). Estudos com o LPG constataram 
que esta molécula também é responsável pela ligação do parasito à membrana dos macrófagos (PINTO et al., 2000).

Após a penetração, o LPG inibe a fusão do lisossomo ao fagossomo, protegendo a forma promastigota das enzimas proteolíticas e do $\mathrm{pH}$ ácido, permitindo a transformação em amastigota, forma resistente ao baixo pH (BOGDAN; ROLLINGHOFF, 1998).

Neutrófilos e macrófagos dispõem de dois mecanismos importantes para a destruição da Leishmania, a formação de superóxidos pelo complexo NADPH oxidase e a síntese de óxido nítrico catalisada pela enzima sintetase de óxido nítrico2 (NOS-2) (MOSSALAY et al., 1999). As espécies de Leishmania são capazes de interferir em ambas as vias através do LPG, inibindo a proteína quinase $C$ (PKC), enzima chave para a explosão oxidativa, impedindo sua translocação do citossol para a membrana plasmática (BOGDAN; ROLLINGHOFF, 1998).

Outra molécula importante para a modulação da resposta imune do hospedeiro é a LACK (receptor de Leishmania homólogo à quinase C ativada), que é capaz de ligar-se aos receptores $\mathrm{V} \alpha 8$ e $\mathrm{V} \beta 4$ presentes nas células T CD4 ${ }^{+}$, estimulando a produção de IL-4 (SCHILLING; GLAICHENHAUS, 2001).

Além disso, 40 proteíno-quinases expressas em grande quantidade na superfície do parasito na fase de penetração no mamífero hospedeiro são capazes de fosforilar componentes do sistema complemento, causando a inibição da via clássica e da alternativa (NORONHA et. al., 1998). Um exemplo é a metaloproteinase gp63, que é capaz de acelerar a conversão do C3b para C3bi, o qual funciona como fator opsonizante da Leishmania, facilitando sua penetração no macrófago, sem que haja a ativação de substâncias microbicidas, através do receptor de complemento do macrófago, CR3 (BRITTINGHAM et al., 1995). A 
gp63 também atua protegendo o parasito da citólise intralisossomal e da degradação, através de sua atividade proteolítica (MC CONVILLE et al., 1987; NORONHA et al., 1998).

A ativação de linfócitos $\mathrm{T} \mathrm{CD}^{+}$, necessária para o desenvolvimento da resposta, requer a apresentação de antígenos pelo complexo principal de histocompatibilidade classe II (MHC classe II), presente nas células apresentadoras de antígenos, e a interação entre receptores co-estimulatórios (B7/CD28, CD40/CD40L) (DE SOUZA et al., 1995). A gp63 presente nas diferentes espécies de Leishmania é capaz de clivar as moléculas de MHC-II, diminuindo sua a expressão na superfície da célula apresentadora de antígeno. Além disso, alguns parasitos são capazes de inibir a expressão de B7-1, molécula co-estimulatória presente na membrana do macrófago, impedindo esta célula de responder ao estímulo do IFN- $\gamma$ (BARRAL-NETTO et al., 1995a; BOGDAN; ROLLINGHOFF, 1998).

\subsection{Regulação da resposta imune na leishmaniose visceral}

A leishmaniose visceral é caracterizada por promover hiperplasia de células do sistema fagocítico mononuclear, mais precisamente no baço, fígado e medula óssea, onde os parasitos se multiplicam (CORBETT; LAURENTI, 1998).

Após a inoculação do parasito na pele, as formas flageladas - promastigota penetram nos macrófagos, transformam-se em amastigotas e multiplicam-se nos vacúolos parasitófagos. A interação entre os ligantes dos parasitos e os receptores celulares ocorre direta ou indiretamente (através de moléculas como C3b/C3bi ou fibronectina). C3bi funciona como uma opsonina e facilita ligação de promastigotas 
com o receptor de complemento tipo três, CR3, dos macrófagos. As promastigotas se protegem da lise pelo complemento através de vários mecanismos, incluindo a liberação do complexo de ataque à membrana e inativação de fatores do complemento (BOGDAN; ROLLINGHOFF, 1997).

As conseqüências, evolução e severidade da LV em mamíferos dependem da resposta imune celular do hospedeiro, especialmente do perfil de produção de citocinas (BARRAL-NETTO, 1992). Esse perfil de produção de citocinas varia conforme constituição genética do indivíduo, fatores inerentes ao parasito como espécie, cepa e tamanho do inóculo e, possivelmente, da presença de produtos da saliva do vetor no local de inoculação dos parasitos (GRIMALDI; TESH, 1993).

A resistência à infecção por Leishmania está ligada à ativação de células $T$ CD4+ do tipo Th1, com uma produção significativa de IFN- $\gamma$ e IL-2. Esse tipo de resposta é induzida por IL-12, citocina esta que ativa resposta imune celular do tipo Th1 e inibe resposta do tipo Th2 (GAZZINELLI, 1993; HEUFLER, 1996; TRINCHIERI, 1993).

A morte dos parasitos do gênero Leishmania dentro de macrófagos, por ativação de mecanismos microbicidas, in vivo, pode ser mediada pelo óxido nítrico (NO) o qual é originado através do metabolismo da L-arginina (LIEW et al., 1990) em resposta a ativação pelo IFN- $\gamma$, produzido pelas células Th1. Sendo assim, a capacidade dos macrófagos em destruir os parasitos no seu interior, depende de sua prévia ativação por citocinas produzidas pelas células T (PINELLI et al., 1999). A reduzida produção de IFN- $\gamma$ e IL-2 por linfócitos de sangue periférico de pacientes com a doença ativa mostram o papel importante destas cotocinas numa adequada ativação da célula hospedeira para destruição de parasitos (CARVALHO et al., 1985). A susceptibilidade a leishmaniose é usualmente ligada à indução de uma 
resposta do tipo Th2 e conseqüente produção de IL-4 (PINELLI et al., 1995), de fatores que desativam macrófagos, como: IL-10, TGF- $\beta$ e prostaglandina $E_{2}$, e que induzem a diferenciação de células B para a produção de anticorpos das classes $\lg$ 1 e IgE (BOGDAN; ROLLINGHOFF, 1997). Dentre os fatores do parasito que podem contribuir para a gênese deste tipo de resposta, temos a taxa de infecção por Leishmania, que interfere na apresentação de antígenos aos linfócitos $\mathrm{T}$ e conseqüentemente no curso da doença (BARRAL-NETO et al., 1995); substâncias como o lipofosfoglicano (LPG), um glicoconjugado da superfície da Leishmania, que promove efeitos inibitórios sobre as enzimas lisossomais e hidrolíticas das células hospedeiras (PRASAD, 1999).

Assim, em seres humanos e em cães, o perfil de susceptibilidade na leishmaniose está associado à presença de manifestações clínicas, evidências de baixa resposta imune celular (teste cutâneo de Montenegro negativo e resposta linfoproliferativa baixa ou ausente) e presença de resposta imune humoral exacerbada (altos níveis de anticorpos anti-Leishmania no soro) (PARANHOS-SILVA et al., 1996).

\subsection{Leishmanose visceral canina}

A leishmaniose visceral canina (LVC) causa grande variedade de sinais clínicos incluindo febre intermitente, letargia, alterações do apetite, emaciação, anemia, esplenomegalia, linfoadenopatia, lesões cutâneas como seborréia seca, prurido, ulcerações, onicogrifose, entre outras (LONGSTAFFE et al., 1983; BURACCO et al., 1997; CIARAMELLA et al., 1997; FEITOSA et al., 2000). Outros 
sintomas são observados como problemas locomotores, alterações renais, diarréia, alopecia periocular, epistaxis (LONGSTAFFE et al., 1983), uveíte (GARCIAALONSO et al., 1996), osteosinovite, artrosinovite, (BURACCO et al., 1997) e paresia de membros posteriores.

Apesar da grande diversidade de sinais clínicos da LVC, existem animais aparentemente saudáveis e aqueles que exibem sintomatologia característica de estágios finais da doença. Um fato intrigante é que a doença canina pode permanecer clinicamente inaparente por longos períodos (LONGSTAFFE et al., 1983). Numerosos pesquisadores observaram a forma assintomática. Falchetti e Faurebrac em 1932 observaram, na França, que a metade dos 32 cães estudados não apresentava sinal clínico algum. Em Malta, Adler e Theodor em 1932 encontraram índices semelhantes, onde $60 \%$ dos cães eram saudáveis. Na Grécia, observou-se que a metade da população canina parasitada mostrava aparência normal (GENARO, 1993). Um estudo em Sobral, no Ceará (DEANE; DEANE, 1955) mostrou que $8 \%$ dos cães infectados apresentavam ausência de sinais clínicos da doença. Em Fortaleza, foi observado por Alencar et al. (1956) que 30,7\% dos cães infectados não apresentavam qualquer sinal clínico. Brener (1957) verificou em uma área endêmica de Minas Gerais, cães infectados que apresentavam aspecto saudável perfazendo um total de $29,5 \%$.

As alterações laboratoriais, particularmente as hematológicas, revelam anemia normocrômica, linfocitose com leucopenia que pode ser moderada ou intensa, neutrofilia e trombocitopenia (KEENAN et al., 1984, ABRANCHES et al., 1991). Na LVC, apesar dos níveis de proteínas totais estarem aumentados, ocorre uma desproteinemia. Na eletroforese do soro observa-se uma inversão da relação albumina/globulina, com aumento da fração gama, o que caracteriza uma 
hipergamaglobulinemia, com diminuição da albumina em alguns casos (KEENAN et al., 1984).

Imunocomplexos circulantes foram detectados em cães com LVC e, através de técnicas de imunomarcação, foram identificados quando depositados nos glomérulos, nas áreas mesangiais e ao longo da membrana basal glomerular e tubular (TAFURI et al., 1989; POLI et al., 1991).

As alterações histopatológicas dos órgãos encontradas na LVC são similares às descritas na doença humana (KEENAN et al., 1984), embora as lesões cutâneas nos cães sejam mais intensas e estejam presentes em grande parte dos casos.

Os órgãos linfóides são alvos na doença. Os linfonodos encontram-se freqüentemente enfartados, com perilinfoadenite, hipertrofia dos cordões e dos folículos, intensa fibrose, seios dilatados e hiperplasia de macrófagos. População reduzida de linfócitos e proliferação de macrófagos nas áreas paracorticais e cordões medulares, hiperplasia folicular e plasmocitose intensa foram também observadas (KEENAN et al., 1984; CORBETT et al., 1992).

A esplenomegalia nem sempre está presente, ou pode ser discreta, moderada ou intensa. Outra alteração freqüentemente encontrada é a periesplenite. Este órgão apresenta uma diminuição de linfócitos na bainha linfóide periarteriolar e proliferação de macrófagos nesta região; hiperplasia folicular e aumento da polpa vermelha com agregados de macrófagos e plasmócitos (KEENAN et al., 1984; TAFURI et al., 2001).

$\mathrm{Na}$ medula óssea há maior celularidade, decorrente da proliferação de macrófagos que podem ou não conter parasitos (KEENAN et al., 1984). A hipoplasia medular, principalmente de células brancas associada à identificação de macrófagos 
parasitados foi referido por Tafuri et al. (2001).

O fígado, geralmente encontra-se aumentado de volume, apresentando um infiltrado plasmo-linfocitário e hiperplasia das células de Küpffer (KEENAN et al., 1984), porém sendo raro o achado do parasito (DUARTE et al., 1989). Geralmente ocorre uma hepatite difusa acompanhada de reação inflamatória exsudativa com infiltrado linfo-plasmocitário nos espaços portais (TAFURI et al., 2001).

\subsection{Diagnóstico da leishmaniose visceral canina}

Em áreas endêmicas, ou durante epidemias, o diagnóstico clínico, concomitante ao aparecimento de anemia e leucopenia, pode ser o suficiente para a confirmação de leishmaniose. O diagnóstico laboratorial clássico é o parasitológico e depende da demonstração dos parasitos em cultura, formas promastigotas, ou em lâminas coradas de biópsias de pele ou aspirados de medula óssea ou de baço, formas amastigotas. Porém, nestes casos, as coletas e os exames das amostras requerem muito treinamento e cuidado na preparação, além de serem métodos invasivos, dolorosos e de baixa sensibilidade (BRAGA et al., 1998; FERRER et al., 1999; ASHFORD et al., 2000).

Em função da necessidade de se utilizar técnicas cada vez mais sensíveis, baratas, simples e rápidas, diferentes métodos de identificação de cães infectados foi proposta a detecção de anticorpos anti-Leishmania por reação de fixação do complemento ou pelo teste de imunofluorescência indireta (IFI) em eluato de papel filtro. Este último é considerado teste padrão ouro e é adotado para inquéritos soroepidemiológicos pela Fundação Nacional de Saúde, órgão do Ministério da 
Saúde responsável pelo controle da leishmaniose no Brasil (BRAGA et al., 1998; CHATTERJEE et al., 1999). Outros testes que também utilizam a detecção de imunoglobulina G ( $\lg G$ ) anti-Leishmania foram propostos, tais como: teste de hemaglutinação indireta, teste de aglutinação em látex, teste de aglutinação direta (DAT), ensaios imunoenzimáticos (ELISA, Competitive-ELISA, DOT-ELISA, FASTELISA, FML-ELISA, PEG-ELISA); teste rápido de anticorpo anti-Leishmania donovani (TRALd), teste de imunoensaio com ouro coloidal e "Western blotting" (BERRAHAL et al., 1996; MANCIANTI et al., 1996; QUIJADA et al., 1996; AZAZY et al., 1997; BERNARDINA et al., 1997; ASHFORD et al., 1998; BRAGA et al., 1998; CABRERA et al., 1999; CHATTERJEE et al., 1999; FERRER, 1999; MILES et al., 1999; REITHINGER; DAVIES, 1999).

A utilização de um teste sorológico levanta alguns questionamentos como: possuir anticorpos contra o parasito não significa que o cão esteja doente e sim que desenvolveu uma resposta humoral ao parasito ou a algum antígeno com reação cruzada a ele; nenhum teste sorológico é $100 \%$ sensível, ou seja, alguns cães nos estágios iniciais da doença são soronegativos; títulos anti-Leishmania permanecem altos por longos períodos de tempo mesmo após a cura clínica; métodos sorológicos (com exceção do Western blotting) não são adequados para verificar a cura ou a eficiência do tratamento (FERRER, 1999).

Técnicas de biologia molecular têm sido usadas no diagnóstico da LVC, como a reação em cadeia de polimerase (PCR), que por ser um método muito sensível, pode ser utilizado em amostras antigas, como as conservadas em parafina. Porém, tem a desvantagem de ser uma técnica onerosa, necessitar de um laboratório mais bem equipado e de pessoal qualificado para sua realização (FERRER, 1999). 
A realização de ensaios de linfoproliferação auxilia no estudo do padrão de resposta imune celular a diferentes antígenos apresentados. A imunidade mediada por células é vital para o desenvolvimento de resistência e cura, enquanto anticorpos anti-Leishmania tem pouco ou nenhum papel na proteção. Cães com infecções latentes têm altos títulos de anticorpos, mas nenhuma proliferação de linfócitos específica para Leishmania (CORRENTI; ORTEGA, 1994; HOMMEL et al., 1995; JAFFE, 1999; MORENO et al., 1999; RHALEM et al., 1999a; RHALEM et al., 1999b).

\subsection{Tratamento da leishmaniose visceral canina}

As drogas anti-Leishmania são geralmente caras e ineficientes no caso do tratamento da LVC e somente uma remissão temporária dos sintomas clínicos, sem a resolução da doença, é obtida. A falha terapêutica tem importantes implicações epidemiológicas, pois os cães permanecem de forma assintomática podendo infectar os flebotomíneos, além de que sucessivos ciclos ineficazes de tratamento levam ao risco da seleção de linhagens de parasitos resistentes às drogas, com claro perigo à saúde humana (MORENO et al., 1999).

O tratamento da LVC tem se desenvolvido recentemente em três tendências: um aumento no tempo do tratamento; a administração da droga em menores intervalos de tempo (um a duas vezes ao dia); e a associação do glucantime (antimoniato de meglumine $75 \mathrm{mg} / \mathrm{kg} / \mathrm{dia}$ por via subcutânea durante vinte ou trinta dias ou enquanto permanecerem os sinais clínicos) ao allopurinol (20 a 30mg/kg/dia por via oral, durante o mesmo período do glucantime e após isso a manutenção do tratamento por mais doze meses com a administração por uma semana no mês). $O$ tratamento com o glucantime tem demonstrado algumas desvantagens como: a 
seleção de parasitos resistentes a droga com o passar do tempo, levando ao risco de selecionar linhagens de parasitos resistentes; o tratamento é doloroso e, para animais de grande porte, é caro; o tratamento dá a falsa impressão de efetividade, o que leva aos proprietários decidirem tratar pessoalmente dos animais por curtos períodos, aumentando o risco de falhas no tratamento. Existem algumas alternativas ao tratamento convencional, como: a anfotericina $B$, que é mais barata e tem um grande potencial na substituição das existentes; a paromomicina (aminosidine), que possui alguns efeitos colaterais como insuficiência renal; os azoles, como os imidazóis e o isethionato (dimethasulfonato) pentamidine ou lomidine, que é utilizado no tratamento de tripanosomiases, babesia, piroplasmose e leishmaniose, porém é muito doloroso por causa de seu excipiente. Outras drogas estão sendo testadas atualmente, como a ilmofosine, edelfosine, milfetosine e a SR 62-834, todas derivadas de 4-alquil lisofosfolipides (FERRER et al., 1995; MORENO et al., 1999; RHALEM et al., 1999,).

\subsection{Patogênese da leishmaniose visceral canina}

A patogênese da leishmaniose visceral canina induzida pela Leishmania (Leishmania) chagasi, nas nossas condições ambientais, ainda necessita de estudos mais aprofundados, pois a maior parte da literatura se refere à patogênese da doença causada pela L. (L.) infantum em condições naturais ou experimentais de infecção ou, por analogia, a estudos da medicina humana e experimental (KONTOS et al.,1993; QUINNELL et al., 2003).

Evidências sorológicas levantam a possibilidade de que a relação entre a $L$. (L.) chagasi e seus hospedeiros vertebrados na América do Sul podem ser 
diferentes daqueles que ocorrem entre L. (L.) infantum e seus hospedeiros no mediterrâneo (BERRAHAL et al., 1996).

Torna-se necessário um estudo esclarecedor sobre o quadro de manifestações clínicas da infecção e correlação com a transmissão para o vetor. Assim, será possível avaliar as implicações dos fatores ambientais, determinantes da dinâmica da doença, gerando situações como a concomitância e similaridade com outras patologias, que possam induzir à erros de diagnóstico. Dessa forma pode-se elaborar um quadro mais fidedigno da doença natural causada nos cães pela L. (L.) chagasi.

Em cães, a Leishmania coloniza todos os órgãos, em contraste com que ocorre em seres humanos, nos quais o parasito está total ou quase totalmente restrito ao sistema hematopoiético (SLAPPENDEL et al., 1990; BERRAHAL et al., 1996).

A leishmaniose, canina ou humana, pode ser considerada uma doença imunológica, devido à capacidade do parasito de modificar o sistema imune do hospedeiro. A infecção é caracterizada por uma resposta policlonal de células B, levando a uma grande produção de anticorpos inespecíficos e específicos contra os antígenos parasitários. Esta hipergamaglobulinemia além de se mostrar ineficaz, pode ser responsável por fenômenos autoimunes tais como a formação de anticorpos antinucleares, e pela presença de imunocomplexos circulantes. Os imunocomplexos circulantes são produzidos em condições normais, mas sua formação pode ser intensificada em alguns processos patológicos caracterizados pela presença de antígenos circulantes persistentes. Na leishmaniose canina, a deposição dos imunocomplexos e subsequente ativação do sistema complemento 
tem sido associada com vasculite, uveíte, artrite, dermatite e especialmente glomerulonefrite e falha renal (LOPEZ et al.,1996).

A produção de subclasses de imunoglobulinas $G(\mathrm{lg})$ varia de acordo com o estímulo antigênico e conseqüente perfil de citocinas produzidas. Em camundongos, IL-4 promove a produção de $\lg G 1$ e $\lg E$ enquanto IFN- $\gamma$ a produção de IgG2a. Em cães estudos vem demonstrando haver uma correlação entre doença e produção de lgG1, já os cães assintomáticos e com resposta celular específica apresentavam maior produção de IgG2 (FERNANDES-PEREZ et al., 2003). Em humanos verificouse que altos níveis de $\lg E$ específica contra o parasito está associada a presença de doença ativa (ATTA et al., 1998). A dosagem de IgG1, IgG2 e IgE pode auxiliar na caracterização da resposta imunológica canina.

As formas promastigotas inoculadas na pele através do flebótomo vetor são fagocitadas pelas células monocíticas podendo ser destruídas ou escapar da lise e proliferar em seu interior. Esta etapa é crucial para o desenvolvimento da resposta imune do hospedeiro (KONTOS; KOUTINAS, 1993). Como a Leishmania é um parasito intracelular obrigatório, a defesa imunológica dependerá da atividade das células $T$ que por sua vez é determinada pela produção de citocinas que as subdivide em células $\mathrm{T}$ auxiliares 1 (Th-1) e células $\mathrm{T}$ auxiliares 2 (Th-2). Uma resposta efetiva contra o parasito basea-se numa resposta Th-1 na que consiste na produção de citocinas como IL-2, IFN- $\gamma$ e TNF- $\alpha$ que dentre diversas ações ativa macrófagos, estimulando a lise do parasito (QUINNELL et al., 2001).

A maioria dos cães desenvolve uma resposta Th-2, inefetiva contra o parasito, caracterizada pela produção de IL-4 e IL-10. Citocinas imunossupressoras que inibem a destruição das Leishmania pelo macrófago permitindo a disseminação das formas amastigotas. Ao mesmo tempo há o aumento da produção e ativação de 
linfócitos B que promovem uma alta de anticorpos específicos e inespecíficos sem ação no controle da doença (SLAPPENDEL; GREENE, 1990).

A leishmaniose visceral canina pode se apresentar com prolongados períodos assintomáticos, sendo que, em estudos epidemiológicos, aproximadamente metade dos cães parasitados não apresenta nenhum sintoma. Relatos de percentagem de cães infectados assintomáticos variaram entre 53,8\% (ABRANCHES et al., 1991) a 59\% (POZIO et al., 1981).

Estudos realizados em cães com infecção natural, na França, sugeriram a existência de dois tipos de formas clínicas, as patentes e as latentes. Neste último grupo estão as formas pré-clínicas, cerca de 90\%, e as formas resolutivas, cerca de 10\% (MARZOCHI, 1985).

Pozio et al. em 1980, demonstraram que, após o período de um ano, entre os animais sintomáticos, $12 \%$ continuavam patentes e $88 \%$ morriam. Entre os assintomáticos, 52\% apresentavam cura espontânea, com negativação da imunofluorescência, $12 \%$ continuavam assintomáticos, $18 \%$ tornavam-se sintomáticos e $18 \%$ morriam no fim do período.

A maioria dos cães presente em áreas endêmica possivelmente já teve contato com a Leishmania. O número de indivíduos infectados sem sinais clínicos da doença é aparentemente muito maior do que o número de sintomáticos (BERRAHAL et al., 1996).

A infectividade de cães com a leishmaniose aguda parece ser independente da extensão das manifestações clínicas da doença, sendo que cães assintomáticos podem ou não ser infectantes para os vetores flebotomíneos a depender do tempo de infecção e resposta imune do animal (TRAVI et al., 2001). Para propósitos epidemiológicos, é imprescindível uma estimativa precisa do número de portadores 
assintomáticos capazes de transmitir a doença. Isto diminuiria o número de cães eliminados e favoreceria a manutenção de cães resistentes à doença (MORENO; ALVAR, 2002).

O estudo da pele é importante, pois é a porta de entrada para o parasito e pode determinar o tipo de resposta imune gerada pelo hospedeiro e também é onde ocorre a infecção do flebótomo com as formas amastigotas (KEMP et al., 1996). Além disso, pouco se sabe sobre os mecanismos envolvidos na localização da Leishmania na pele dos animais com LVC. Verificar as diferenças imunopatológicas presentes na pele de animais infectados possíveis transmissores ou não do parasito poderá elucidar os mecanismos de transmissão da doença.

O tipo de infiltrado inflamatório presente na pele canina pode refletir o perfil de resposta imunológica contra o parasito e pode ser considerado como marcador morfológico de susceptibilidade ou resistência à infecção (LEMOS DE SOUZA et al., 2000).

Alguns estudos nesta área verificaram que pode haver uma relação entre a sintomatologia e o aspecto histológico da pele. Cães assintomáticos e/ou oligossintomáticos apresentaram número moderado de células de Langerhans, poucos queratinócitos expressando MHC-classe II e reduzido número de macrófagos. Enquando que os animais com doença severa apresentavam grande quantidade de macrófagos com vacúolos repletos de parasitos, poucas células de Langerhans e queratinócitos sem expressão de MHC classe II representando um padrão de susceptilidade (FONDEVILLA et al., 1997; SOLANO-GALEGO et al., 2004).

Pesquisar a relação entre a resposta imune sistêmica e o padrão imunopatológico da pele destes animais poderá favorecer o entendimento da relação 
entre infecção e transmissão da doença (FONDEVILA et al., 1997; SOLLANOGALLEGO et al., 2004; DOS-SANTOS et al., 2004).

O trabalho para a elaboração de um perfil clínico e imunopatológico que possa servir como base para esclarecer questões relacionadas à evolução da infecção no cão, identificando animais infectados transmissores e não transmissores do parasito para o vetor poderá favorecer o controle da doença, além de poder ser utilizado para diferenciar animais imunizados, de animais infectados transmissores.

Os clínicos veterinários, à medida que incorporam em seu instrumental, técnicas específicas de diagnóstico, oferecidas no mercado (AMUSATEGUI et al., 1995), vêm sendo cada vez mais solicitados a tratar os animais infectados, cujos donos recusam-se a entregar para o sacrifício. Além disso, o cão desempenha no nosso meio um papel social muito importante, por participar da estrutura familiar, e exerce funções importantes como guias de cegos, resgate, policiamento e na terapia de pessoas deficientes. A cinofilia representa também uma importante atividade do ponto de vista econômico no país. O sacrifício indiscriminado de cães soropositivos, além ser uma medida onerosa, encontra resistência ética e emocional (NEOGY et al., 1994), sendo questionada sua eficiência na redução da incidência da doença humana (PARANHOS-SILVA et al., 1996; DYE, 1996) ou mesmo sendo esta redução considerada parcial ou nula (MORENO et al., 1999).

Com a comercialização da vacina contra leishmaniose no Brasil será importante para a saúde pública dispor de métodos diagnósticos que possam assegurar que cães imunizados ou tratados não estejam transmitindo a doença para população humana (ALVAR et al., 1994; GUARGA et al., 2002). Atualmente isto só é possível através de xenodiagnóstico um método de difícil execução, pois consiste 
em submeter o animal a picadas do inseto vetor criado em laboratório e posterior verificação de parasitos nos insetos.

\subsection{Interação Leishmania- Vetor}

Os flebotomíneos pertencem a família Psychodidae, ordem Diptera e subfamília Phlebotominae apresentam ampla distribuição geográfica. No Brasil são popularmente denominados de asa branca, birigui, cangalinha, mosquito palha ou tatuquira.

Estes insetos medem de 2 a $4 \mathrm{~mm}$ de comprimento; o corpo é densamente coberto de pêlos finos uma característica peculiar é que quando em repouso as asas são mantidas divergentes em posição semi-ereta (KILLICK-KENDRICK, 1990).

O grande gênero de importância médica no Novo Mundo é o Lutzomia que é formado por 15 subgêneros, 11 grupos de espécies e 17 espécies não agrupadas. No Velho Mundo o gênero Phlebotomus contém as espécies de interesse médico (KILLICK-KENDRICK et al., 1991).

Em comparação com outras famílias de Nematocera de importância médica muito pouco se conhece sobre os locais do desenvolvimento dos flebotomíneos (JARVIS; RUTLEDGE, 1992).

As formas imaturas encontradas no Novo Mundo não são observadas em áreas domiciliares e sim no peridomicílio em locais de grande concentração de matéria orgânica como galinheiros. Na natureza são encontrados em detritos de fendas rochosas, chão de cavernas, no solo entre raízes de árvores por debaixo de folhas mortas e úmidas. Desenvolvem-se no solo úmido, mas não molhado ou em locais ricos em matéria orgânica em decomposição. Devido a dificuldade de 
encontrar locais de desenvolvimento natural, a maior parte da informação sobre os estágios imaturos provém das observações de criações em laboratório (KILLICKKENDRICK et al., 1991; JARVIS; RUTLEDGE, 1992).

A progênie das fêmeas em laboratório, capturadas no campo são mantidas em colônias, porém é um processo de alto custo. $O$ insetário precisa dispor de estufa com controle de temperatura a $25^{\circ} \mathrm{C}$ e $80 \%$ de umidade relativa (KILLICKKENDRICK et al., 1991).

O alimento larval consiste em uma mistura de Daphnia seca e extrato aquoso liofilizado de fígado de galinha e de pólen contendo 24 aminoácidos essenciais. Os adultos são mantidos com acesso constante a solução de sacarose a $10 \%$ e as fêmeas se alimentam em hamsters (KILLICK-KENDRICK, 1990).

Nestas condições as fêmeas produzem 47 ovos por postura. O período médio de incubação é de 6,7 dias e o larval 18 dias. A fase pupal tem duração de 16 dias. O ciclo biológico da oviposição até a eclosão da geração seguinte leva cerca de 36 dias (JARVIS; RUTLEDGE, 1992) .

Os flebotomíneos machos não são hematófagos apenas as fêmeas se alimentam de sangue, o qual é a fonte de proteína e de aminoácidos para o desenvolvimento dos ovos (SHERLOCK et al., 1996b).

Até 40 anos acreditava-se que todas as promastigotas encontradas nos flebótomos apanhados a campo pertenciam ao gênero Leishmania e que todas eram infectáveis para o homem. Sabe-se agora que certos flebotomíneos americanos são suscetíveis à infecção por tripanossomatídeos, sendo indistinguíveis em certos estágios de desenvolvimento de promastigotas de Leishmania (SHERLOCK et al., 1996b). 
O flebótomo fêmea adquire ao alimentar-se em um mamíferoatrvés da ingestão de macrófagos infectados com formas amastigotas, pois essas formas não são encontradas livremente no sangue. A susceptibilidade do flebótomo a infecção por Leishmania depende das interações que ocorrem no trato digestivo, iniciando-se com as alterações de temperatura e pH (BATES, 2007).

Após a infecção o parasito passa por diferentes estágios desde a migração do intestino médio do flebótomo até a porção anterior da cavidade bucal. Cada estágio de desenvolvimento é caracterizado por alterações morfológicas e funcionais capazes de manter o parasito vivo (CUNNINGHAM, 2002).

Inicialmente a amastigota diferencia-se em procíclica, uma forma pequena com um pequeno flagelo e pouco móvel que é resistente as enzimas digestivas do vetor, neste estágio começa seu primeiro ciclo reprodutivo (KAMHAWI, 2006). As formas procíclicas desenvolvem-se em nectomonas formas largas, alongadas e extremamente móveis cuja função é escapar do confinamento da matriz peritrópica para ancorar-se nas células epiteliais e migrar para a parte mais anterior do trato digestivo. Esse escape é facilitado pela produção de quitinases do parasito. As nectomonas diferenciam-se em leptomonas, geralmente no quarto dia após a infecção estas multiplicam-se de forma maciça e produzem um gel glicoproteico importante para a sobrevivência da forma metacíclica que é forma infectiva capaz de sobreviver ao sistema complemento do hospedeiro e perpetuar-se. O tempo apropriado para o parasito completar o seu ciclo evolutivo no flebótomo é de 6 a 9 dias (BATES, 2007).

A adesão e escape do parasito são de fundamental importância para sua sobrevivência, pois caso contrário este seria expulso nas fezes do flebótomo. Uma das moléculas fundamentais na ligação do parasito ao epitélio do intestino do inseto 
vetor é uma glicoproteína (BATES, 2007). A formação do "plug" parasitário envolto por um gel composto basicamente por desta glicoproteína conhecida como proteofosfoglicana filamentosa, é um fator crucial para infecção do parasito por protegê-lo do sistema imune do hospedeiro em seu período inicial de invasão; bem como interfere no comportamento biológico do vetor estimulando um aumento de picadas ao hospedeiro devido a obstrução do canal alimentar causada pelo "plug" parasitário envolto pelo gel (ROGERS, 2004). 
OBJETIVOS 


\section{OBJETIVO GERAL}

Identificar e padronizar os achados clínicos e caracterizar a resposta imune celular e humoral de cães infectados com Leishmania (Leishmania) chagasi correlacionado com transmissão do parasito ao vetor.

\subsection{Objetivos específicos}

Em cães positivos através de diagnóstico parasitológico, realizar:

1- Padronização dos achados clínicos e classificação dos animais em assintomáticos e sintomáticos.

2 - Análise das alterações histológicas e do parasitismo em biópsias de pele, baço e linfonodo destes animais.

3 - Análise a resposta imune celular em biópsias de pele, baço e linfonodo através da técnica de imunoistoquímica utilizando marcadores celulares como: CD3 e macrófagos.

4 - Análise da resposta imune humoral, caracterizando o perfil de lgG total IgG1, IgG2 e IgE em soros de animais sintomáticos e assintomáticos com diagnóstico parasitológico positivo para leishmaniose. 
5 - Comparar o perfil da imunidade humoral e celular em baço, linfonodo e pele de animais assintomáticos e sintomáticos, correlacionando com o potencial de transmissibilidade do parasito ao vetor. 


\section{MATERIAL E MÉTODOS}

\subsection{Animais}

Foram examinados 139 cães provenientes de área endêmica para leishmaniose, na região noroeste do Estado de São Paulo. A população refere-se a cães encaminhados ao Centro de Controle de Zoonoses do município de Araçatuba (SP), escolhidos aleatoriamente no período de 2005 a 2006. Os animais foram examinados clinicamente e de acordo com a sintomatologia foram divididos em dois sub-grupos: sintomáticos e assintomáticos.

Após a anamnese, os animais foram anestesiados com tiopental sódico $25 \mathrm{mg} / \mathrm{kg}$ e sangue total foi obtido através de punção cardíaca. Seguiu-se a eutanásia com a injeção de solução 19\% de cloreto de potássio. Após a morte dos animais, fragmentos de baço, linfonodo e pele do pavilhão auricular foram colhidos para estudos histológicos e imunológicos.

Vinte e oito cães oriundos de região onde não se tem registro de casos autóctones de leishmaniose visceral foram utilizados como controle, constituindo o grupo de animais negativos para leishmaniose. Estes animais pertenciam ao canil da Faculdade de Medicina da USP - São Paulo e eram utilizados em aulas práticas de técnica cirúrgica no Departamento de Técnica Cirúrgica da FMUSP.

\subsection{Diagnóstico parasitológico}


O diagnóstico parasitológico foi feito através de imprint de baço e linfonodo poplíteo, corados pelo Giemsa, e observados em microscopia óptica comum com objetiva de imersão. A confirmação do diagnóstico parasitológico foi feita posteriormente empregando-se a técnica de imunoistoquímica em cortes parafinados incubados com anticorpo anti-Leishmania.

\subsection{Histopatologia}

As biopsias de baço, linfonodo e pele foram colhidas e imersas em solução $10 \%$ de formoldeido tamponado, e processadas pelas técnicas usuais de microscopia ótica para a obtenção de cortes corados pela técnica de hematoxilinaeosina (HE) e para uso em imunohistoquímica.

\subsection{Imunoistoquímica em tecido parafinado para detecção de parasitos, macrófagos e células CD3+ em fragmentos de baço, linfonodo e pele de cão.}

1 - Desparafinização dos cortes histológicos utilizando banho de xilol quente $\left(60^{\circ} \mathrm{C}\right)$ por 15 minutos, posteriormente banho de xilol frio (TA) por 15 minutos.

2 - Hidratação dos tecidos, imergindo em álcool absoluto em dois banhos de 5 minutos, seguidos de banhos sucessivos de 3 minutos em álcool a 70\%, 50\% e $30 \%$, seguidos de um enxágüe em água destilada corrente e água destilada.

3 - Recuperação antigênica em solução de ácido cítrico $10 \mathrm{mM}$ pH 6,0 em banho 
Maria a $96-98^{\circ} \mathrm{C}$ por 30 minutos. Esperar os cortes esfriarem para seguir a reação.

4 - Bloqueio da peroxidase endógena com 6 banhos de 10 minutos com $\mathrm{H}_{2} \mathrm{O}_{2}$ (água oxigenada 20 volumes). Descartar a água oxigenada e colocar em água corrente por 2 minutos, água destilada e dois banhos de 5 minutos em PBS 0,15M pH7,2.

5 - Bloqueio de reação inespecífica com solução a $10 \%$ de leite em pó desnatado (MOLICO) em água destilada, durante 20 minutos, à temperatura ambiente.

6 - Incubação com os anticorpos primários: policlonal anti-Leishmania produzido em camundongo no Laboratório de Patologia de Moléstias Infecciosas - FMUSP na diluição de 1:800, monoclonal anti-macrófago humano produzido em camundongo (Serotec MCA874G) na diluição de 1:800 e anti-CD3 humano produzido em coelho (DakoCytomation A0452) na diluição de 1:120 em PBS com $1 \%$ de albumina bovina durante a noite a $4^{\circ} \mathrm{C}$.

7 - Lavagem das lâminas com PBS por 15 minutos, 3 trocas de 5 minutos.

8 - Incubação com o anticorpo secundário (kit LSAB - DakoCytomation) durante 45 minutos a temperatura ambiente.

9 - Lavagem das lâminas com PBS por 15 minutos, 3 trocas de 5 minutos.

10 - Incubação com solução de estreptavidina-peroxidase (kit LSAB DakoCytomation), durante 30 minutos à temperatura ambiente.

11 - Lavagem das lâminas com PBS por 15 minutos, 3 trocas de 5 minutos.

12 - Revelação da reação foi feita com o substrato cromogênico, solução de diaminobenzidina (DAB) 0,06 mg/100 mL de PBS, acrescida de $1 \mathrm{ml}$ de peróxido de hidrogênio 20 volumes, por 5 minutos a temperatura ambiente. A reação foi interrompida com água destilada. 
13 - A contra-coloração dos cortes foi feita com hematoxilina de Mayer por 3-5 minutos. Após lavagem dos cortes em água corrente e água destilada, segui-se desidratação dos cortes e montagem das lâminas com bálsamo diluído em xilol. 14 - Os cortes foram observados em microscopia de luz convencional utilizando-se a objetiva de $40 \mathrm{X}$.

A análise semi-quantitativa das reações de imunoistoquímica foram feitas comparativamente, considerando: (0) negativo ou ausente, (1) discreto, (2) moderado e (3) intenso, para o parasitismo e expressão de células T CD3 ${ }^{+}$e macrófagos em tecido de pele, baço e linfonodo poplíteo.

\subsection{ELISA}

\subsubsection{Produção de antígeno}

Promastigotas de Leishmania (Leishmania) chagasi foram isoladas a partir de baço de hamster cronicamente infectado, em meio de cultura RPMI suplementado com $10 \%$ de soro fetal bovino inativado pelo calor, $2 \%$ de urina humana, $10 \mu \mathrm{g} / \mathrm{ml}$ de gentamicina e $100 \mathrm{UI} / \mathrm{ml}$ de penicilina. Após 2-3 passagens em cultura, promastigotas em fase estacionária de cultivo foram lavadas 3 vezes em PBS estéril, 3000 rpm por 10 minutos, e estocadas em freezer $-80^{\circ} \mathrm{C}$. Para o preparo do antígeno, o pellet contendo as formas promastigotas do parasito foi congelado em nitrogênio líquido e descongelado em temperatura ambiente por 3 vezes 
consecutivas; depois sonicado em potência 4 em 1 ciclo de 1 minuto (Sonic Desmembrator, Fisher Scientific, USA). Segui-se centrifugação 14.000 rpm por 10 minutos a $4^{\circ} \mathrm{C}$, o sobrenadante foi coletado, do qual obteve-se alíquota para a dosagem de proteínas pelo método de Bradford.

\subsubsection{Ensaio para determinação de $\lg G$}

1. Microplacas de poliestireno de fundo plano de 96 poços foram sensibilizadas com um volume de $100 \mu \mathrm{L}$ de antígeno solúvel de promastigotas de L. (L.) chagasi, nas concentraçôes de $10 \mu \mathrm{g} / \mathrm{mL}$ de proteína, em tampão carbonato-bicarbonato $0,1 \mathrm{M} \mathrm{pH} 9.5$, e incubadas em câmara úmida durante a noite a $4^{\circ} \mathrm{C}$.

2. As placas foram lavada três vezes com $200 \mu \mathrm{L}$ por poço de Solução Tampão Fosfato 0,15M pH7.2 contendo 0,05\% de Tween-20 (PBS-T).

3. Bloqueio de ligações inespecíficas foi feito com solução de leite em pó desnatado

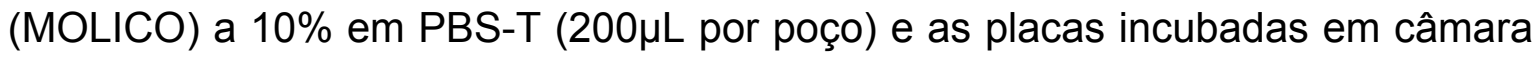
úmida durante 2 horas a $37^{\circ} \mathrm{C}$.

4. As placas foram lavadas novamente três vezes com PBS-T.

5. Amostras dos soros teste, assim como dos soros sabidamente positivos e negativos foram adicionadas à placa, em duplicata, no volume de $100 \mu \mathrm{L}$ por poço, na diluição de 1:400 em PBS-T e incubadas a $37^{\circ} \mathrm{C}$ durante 1 hora em câmara úmida.

6. As placas foram lavadas três vezes com PBS-T. 
7. Conjugado anti-lgG (A40-123AP) de cão ligado a fosfatase alcalina (BETHYL, USA) foi adicionado no volume de $100 \mu \mathrm{L}$ por poço, nas diluições de 1:2000 em PBS-T, sendo as placas incubadas a $37^{\circ} \mathrm{C}$, durante 45 minutos em câmara úmida.

8. As placas serão lavadas três vezes com PBS-T.

9. O revelador contendo o substrato e o cromógeno $(1,0 \mathrm{mg} / \mathrm{mL}$ de pNPP -SIGMA, em tampão carbonato-bicarbonato $0,1 \mathrm{M}$ pH9,5) foi adicionado no volume de $100 \mu \mathrm{L}$ por poço e incubado à temperatura ambiente por 30 minutos.

10. A reação será interrompida com $50 \mu \mathrm{L}$ de $\mathrm{NaOH} 3 \mathrm{M}$ por poço, sendo a leitura da absorbância feita em filtro de $405 \mathrm{~nm}$.

\subsubsection{Ensaio para determinação de $\lg G 1$, $\lg G 2$ e $\lg E$}

1. Microplacas de poliestireno de fundo plano de 96 poços foram sensibilizadas com um volume de $100 \mu \mathrm{L}$ de antígeno solúvel de promastigotas de L. (L.) chagasi, nas concentraçôes de $20 \mu \mathrm{g} / \mathrm{mL}$ de proteína, em tampão carbonato-bicarbonato $0,1 \mathrm{M} \mathrm{pH} 9.5$, e incubadas em câmara úmida durante a noite a $4^{\circ} \mathrm{C}$.

2. As placas foram lavada três vezes com $200 \mu \mathrm{L}$ por poço de Solução Tampão Fosfato 0,15M pH7.2 contendo 0,05\% de Tween-20 (PBS-T).

3. Bloqueio de ligações inespecíficas foi feito com solução de leite em pó desnatado

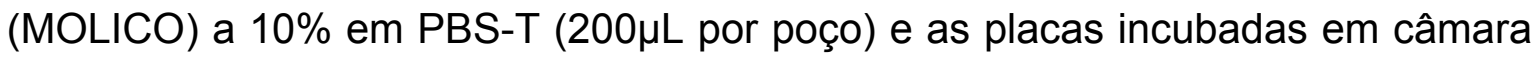
úmida durante 2 horas a $37^{\circ} \mathrm{C}$.

4. As placas foram lavadas novamente três vezes com PBS-T. 
5. Amostras dos soros foram adicionadas à placa, em duplicata, no volume de 100 $\mu \mathrm{L}$ por poço, na diluição de 1:200 para $\operatorname{lgG} 1$ e IgG2 e na diluição de 1:20 para IgE em PBS-T e incubadas a $37^{\circ} \mathrm{C}$ durante 2 horas em câmara úmida e overnight a $4^{\circ} \mathrm{C}$.

6. As placas foram lavadas três vezes com PBS-T.

7. Conjugados anti-lgG1 (A40-120AP), anti-lgG2 (A41-121AP) e anti-lgE (A40125AP) de cão ligado a fosfatase alcalina (BETHYL, USA) foi adicionado no volume de $100 \mu \mathrm{L}$ por poço, nas diluições de 1:500 para lgG1 e IgG2 e 1:50 para IgE em PBS-T, sendo as placas incubadas a $37^{\circ} \mathrm{C}$, durante 60 minutos em câmara úmida.

8. As placas serão lavadas três vezes com PBS-T.

9. O revelador contendo o substrato e o cromógeno $(1,0 \mathrm{mg} / \mathrm{mL}$ de pNPP - SIGMA, em tampão carbonato-bicarbonato $0,1 \mathrm{M}$ pH9,5) foi adicionado no volume de $100 \mu \mathrm{L}$ por poço e incubado à temperatura ambiente por 30 minutos.

10. A reação será interrompida com $50 \mu \mathrm{L}$ de $\mathrm{NaOH} 3 \mathrm{M}$ por poço, sendo a leitura da absorbância feita em filtro de $405 \mathrm{~nm}$.

\subsection{Xenodiagnóstico}

Os experimentos de xenodiagnóstico foram realizados em duas etapas. $\mathrm{Na}$ primeira etapa, foram utilizados 21 animais, sendo 11 sintomáticos e 10 assintomáticos; e na segunda etapa foram utilizados mais 19 animais, sendo 13 sintomáticos e 6 assintomáticos. Estes animais foram selecionados no Centro de 
Controle de Zoonoses do município de Araçatuba (SP) a partir do diagnóstico parasitológico positivo em punção aspirativa de linfonodo poplíteo.

Os animais foram sedados (Acepran 0,05mg/Kg), posteriormente anestesiados (Ketamina $15 \mathrm{mg} / \mathrm{Kg}+$ Diazepan $0,5 \mathrm{mg} / \mathrm{Kg}$ ) e monitorados por um período de 2 horas na Clínica de Pequenos Animais do Hospital Veterinário da UNESP, Araçatuba (SP). Aproximadamente 50 exemplares de Lutzomyia longipalpis colonizados em laboratório a partir de vetores capturados em região não endêmica para leishmaniose (Gruta da Lapinha - MG), foram acondicionados em recipientes individuais com extremidade telada e fixados na parte ventral de uma das orelhas de cada animal. Após este período, os recipientes foram retirados das orelhas e sangue total foi colhido para determinação de $\lg G$, $\lg G 1$, $\lg G 2$ e $\lg E$. Posteriormente, os animais foram sacrificados e fragmentos de pele da orelha, baço, e linfonodo foram colhidos para estudo histológico e imunoistoquímico.

Os vetores utilizados na primeira etapa do trabalho foram mantidos em laboratório com alimentação de solução açucarada e no quarto dia após o xenodiagnóstico as fêmeas foram dissecadas para avaliar a porcentagem de fêmeas alimentadas e a porcentagem de fêmeas que apresentavam formas flageladas no tubo digestivo, sugestivo de formas promastigotas do parasito.

Os vetores utilizados na segunda etapa do trabalho foram congelados em freezer $-80^{\circ} \mathrm{C}$ no quarto dia após o xenodiagnóstico e transportados em gelo seco para o Laboratório de Entomologia Médica do Instituto de Pesquisa Reneé Rachou FIOCRUZ - Belo Horizonte (MG), onde foi feita a extração de DNA individualmente dos flebotomíneos seguindo-se a realização da reação em cadeia pela polimerase (PCR) para detecção de Leishmania. 


\subsection{Análise estatistica}

A análise estatistica foi feita utilizando-se o programa SigmaStat versão 3.1 para os estudos comparativos dos valores de absorbância de imunoglobulinas entre os diferentes grupos. Teste $t$ de student foi utilizado para identificar diferenças significantes entre os grupos; e para os dados não paramétricos, o teste de MannWhitney Rank Sum.

Os testes de Qui-quadrado de Pearson e Fisher foram aplicados para investigar associações entre a intensidade do parasitismo e os níveis de imunoglobulinas test, intensidade de células marcadas para macrófagos e CD3, assim como formas clinicas utilizando-se o programa SPSS para Windows versão 12.0. Os resultados foram considerados significantes quando o valor de $p$ foi igual ou menor do que 0,05 . 


\section{RESULTADOS}

\subsection{Sinais clínicos e parasitismo}

Dos 120 cães estudados, 46\% (55/120) não apresentaram sinais clínicos e foram classificados como assintomáticos e 54\% (65/120) apresentaram sintomas. Os sinais clínicos mais freqüentes foram linfoadenomegalia (77\%), esplenomegalia (66\%), lesões cutâneas (53\%), perda de peso $45 \%$, alopecia $32 \%$, onicogrifose (29\%) e hepatomegalia (28\%) (Figura 1).

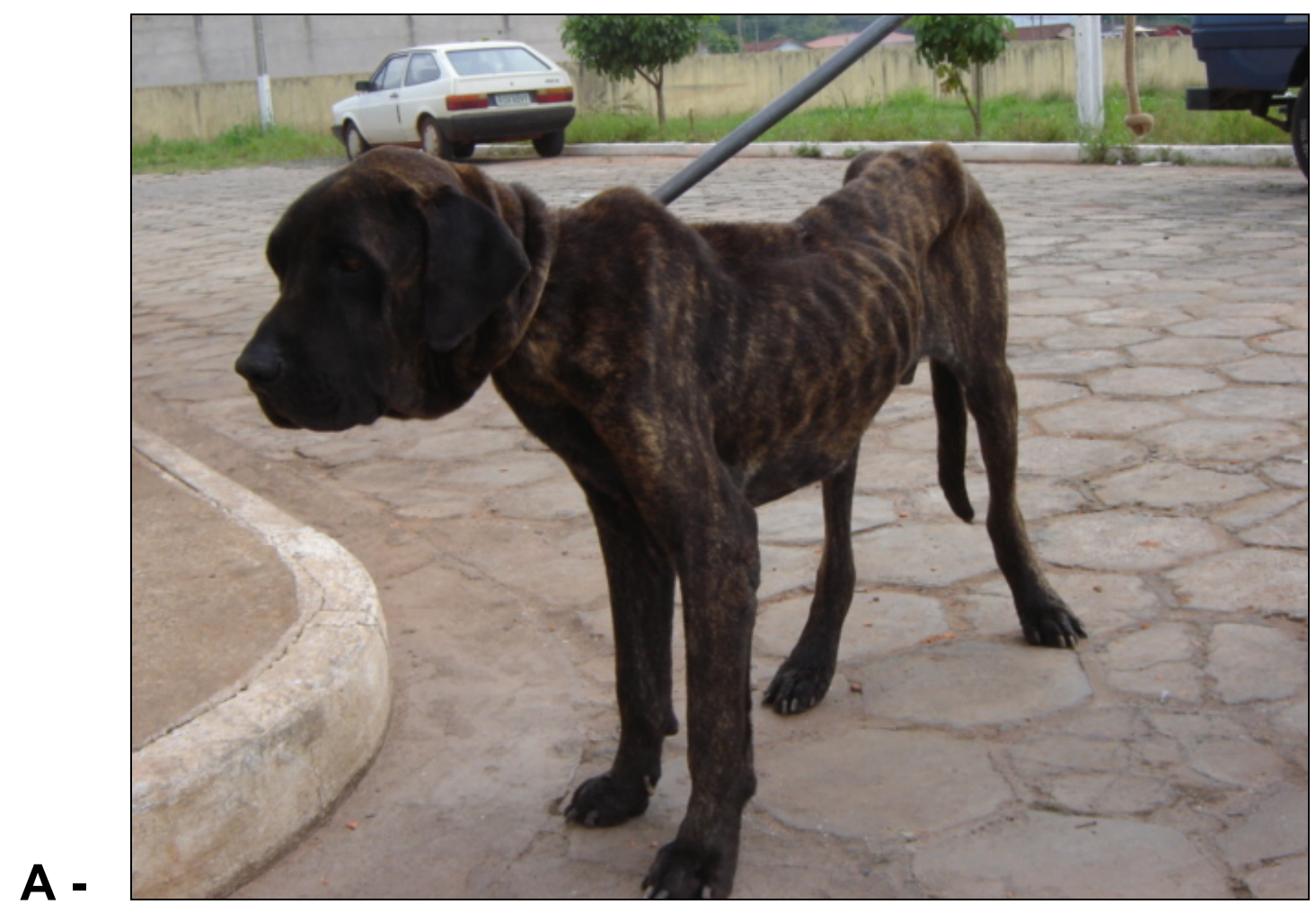



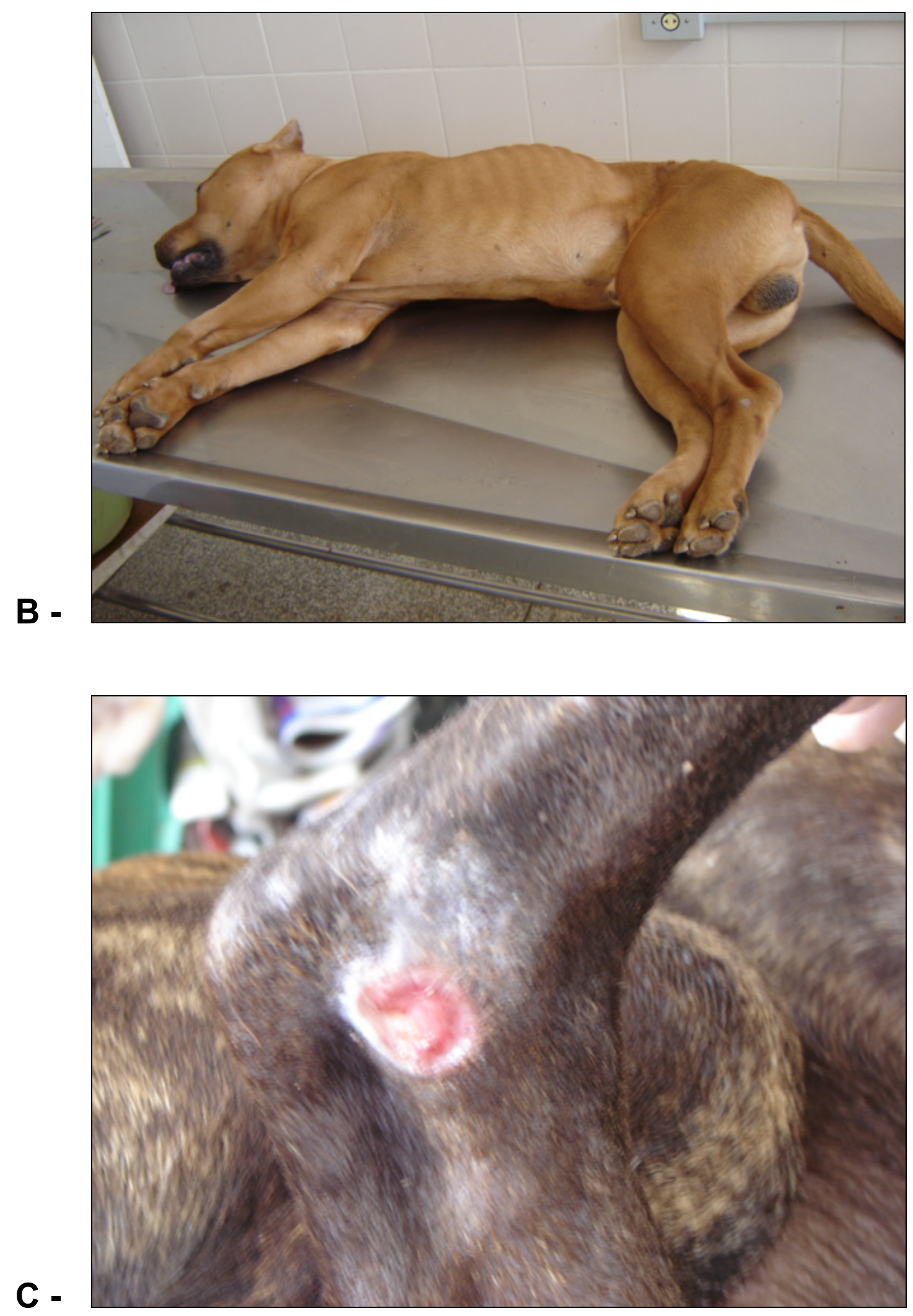

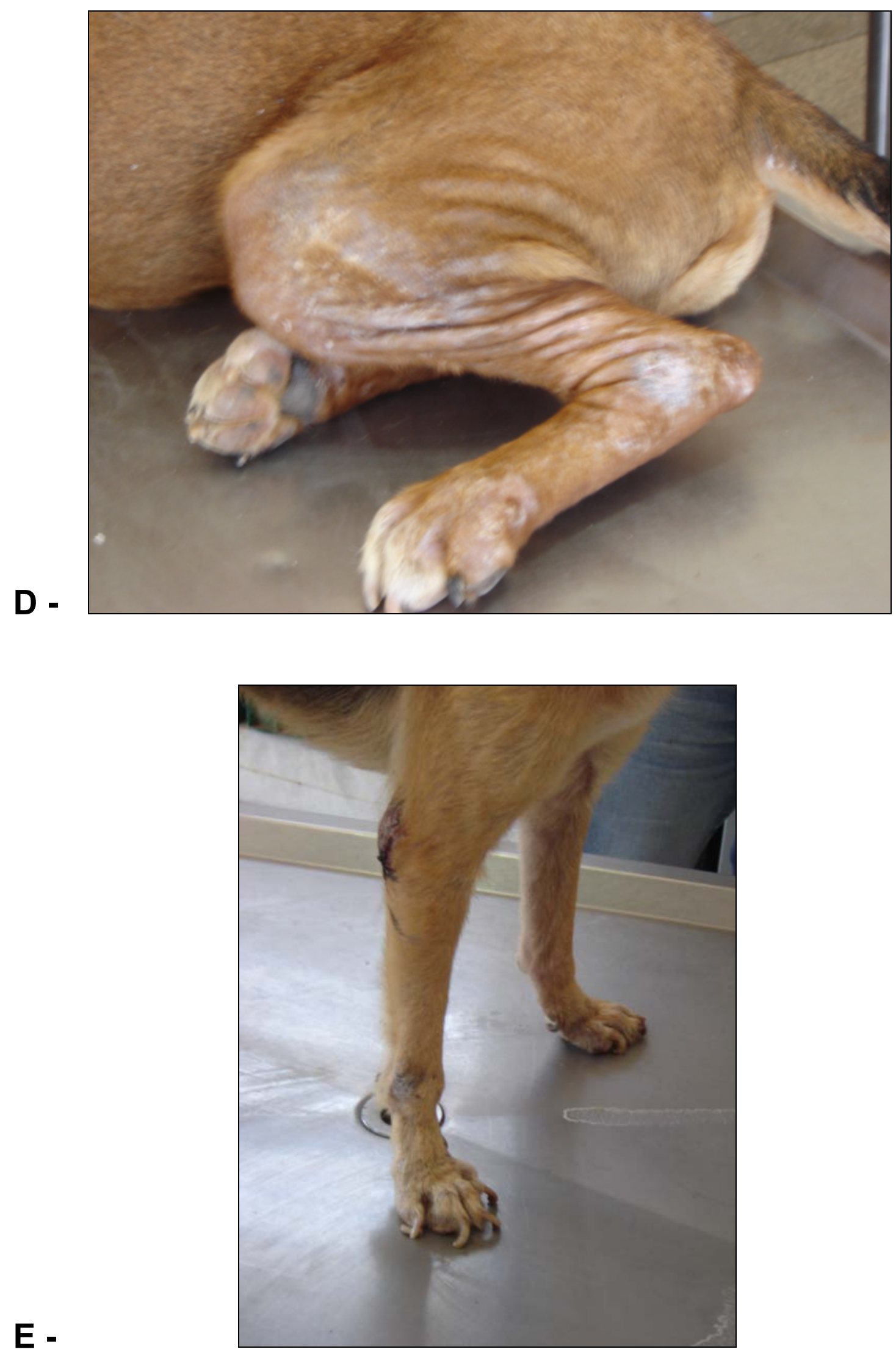

Figura 1 - Aspectos clínicos dos cães estudados. A e B - Emagrecimento; C e D - Lesões de pele, alopecia e úlcera, respectivamente; e E - Onicogrifose 
A presença de formas amastigota de Leishmania em amostras de tecidos foi confirmada através da reação de imunoistoquímica em 43\% (51/120) dos cães em amostra de baço, 48\% (58\%/120) em amostra de linfonodo e 31\% (37/120) em amostra de pele. Dos cães classificados como assintomáticos $40 \%$ (22/55) apresentaram parasitos em vísceras ou pele e dos animais sintomáticos $71 \%(46 / 65)$ apresentaram parasitos em um ou em todos os tecidos estudados.

A correlação estatística entre a presença de parasitos em vísceras e/ou pele e a sintomatologia demonstrou uma correlação positiva entre presença de sinais clínicos e carga parasitaria $(p<0,05)$, enquanto que uma correlação negativa foi encontrada quando comparado a intensidade de carga parasitária e cães assintomáticos (Tabela 1).

\begin{tabular}{c|cccc|cccc|cccc}
\hline & \multicolumn{3}{|c|}{ BAÇO } & \multicolumn{3}{c|}{ LINFONODO } & \multicolumn{5}{c}{ PELE } \\
& $(-)$ & $(+)$ & $(++)$ & $(+++)$ & $(-)$ & $(+)$ & $(++)$ & $(+++)$ & $(-)$ & $(+)$ & $(++)$ & $(+++)$ \\
\hline SINTOMÁTICO & 30 & 15 & 08 & 12 & 24 & 18 & 06 & 17 & 37 & 09 & 08 & 11 \\
ASSINTOMÁTICO & 39 & 04 & 04 & 08 & 38 & 04 & 05 & 08 & 46 & 04 & 03 & 02 \\
\hline
\end{tabular}

Tabela1: Distribuição da carga parasitária em amostras de pele, baço e linfonodo analisados por imunoistoquímica, São Paulo, 2007.

\subsection{Alterações histológicas e parasitismo}

\subsubsection{Pele}


As lesões de pele se caracterizaram por infiltrado inflamatório na derme, perianexal, formado principalmente por células mononucleares: macrófagos, linfócitos e plasmócitos (Figura 2A). O infiltrado inflamatório variou de discreto a intenso, por vezes focal ou difuso. A presença de granulomas epiteliódes com células gigantes foi evidenciada na pele de alguns animais. A presença de formas amastigotas de Leishmania foi confirmada em 37 casos dos 120 estudados nos cortes histológicos da pele processados por imunoistoquímica (Figura 2B).

(A)

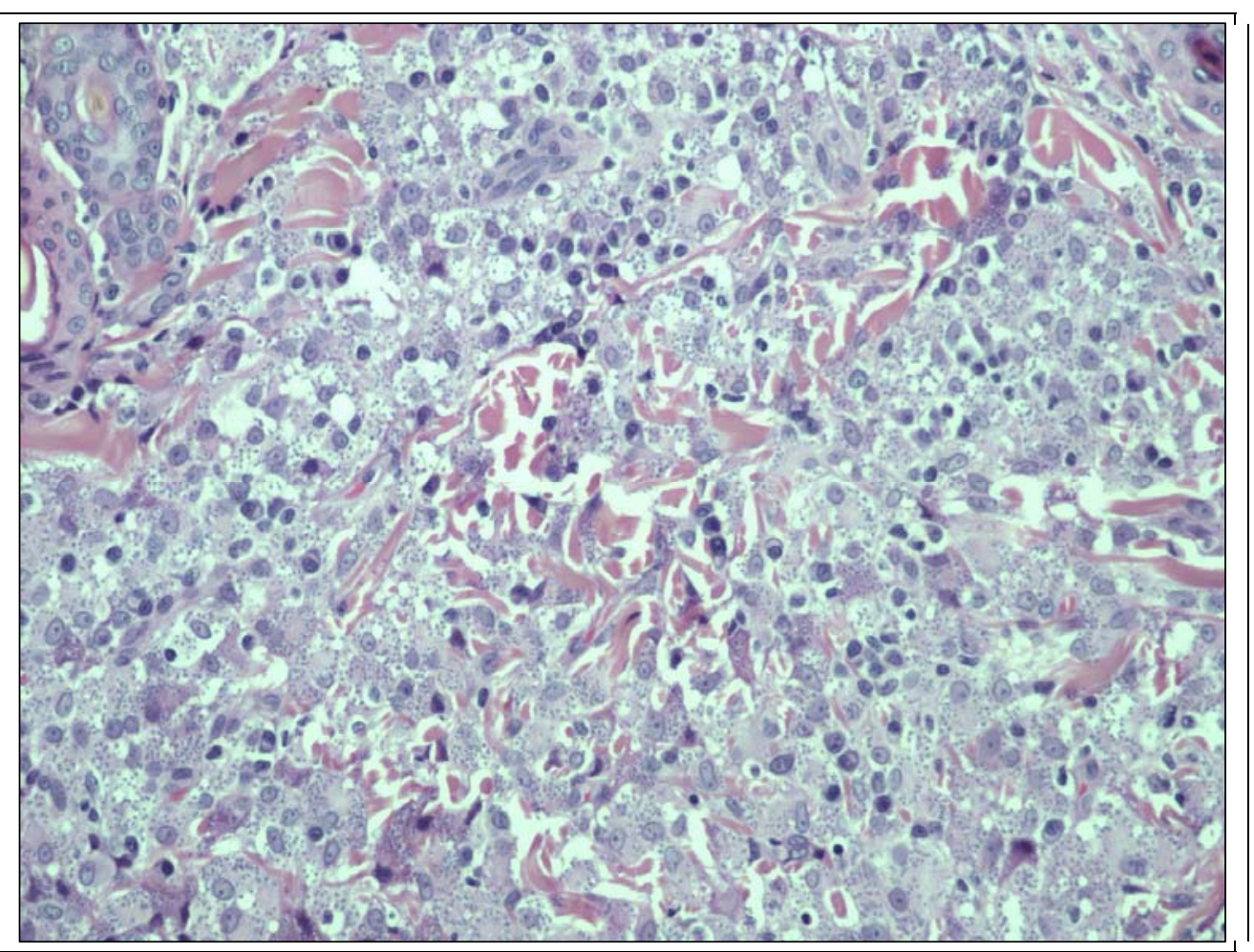




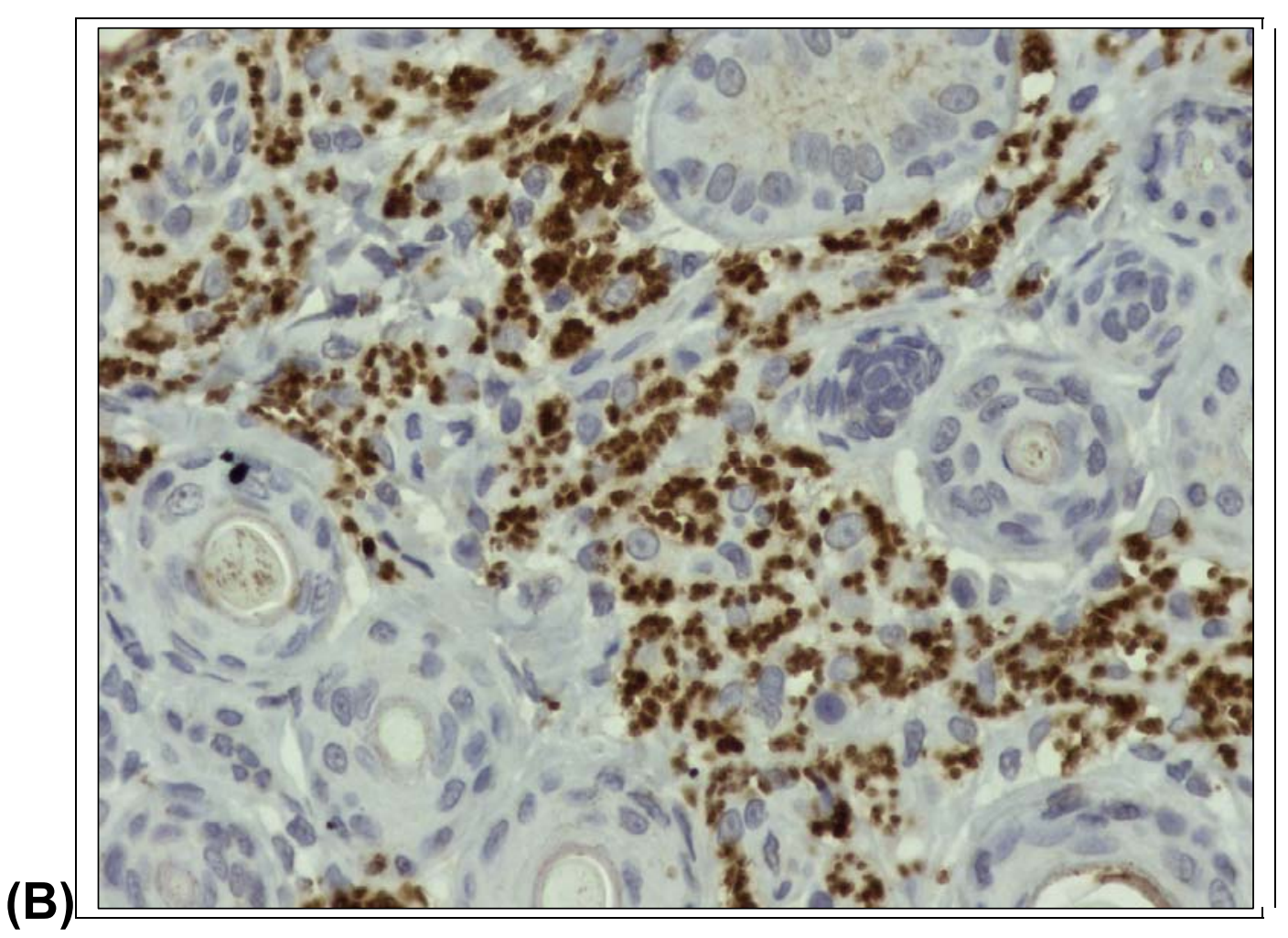

Figura 2 - A: Infiltrado inflamatório mononuclear na derme de cão naturalmente infectado por L.(L.)chagasi (H\&E - objetiva 20X). B: Parasitismo na derme de cão naturalmente infectado por L.(L.)chagasi (ABC - objetiva 40X)

\subsubsection{Linfonodo}

$\mathrm{Na}$ área cortical e para-cortical dos linfonodos foi observada ativação folicular que variou de discreta a moderada (Figura 3A). Hiperplasia e hipertrofia de macrófagos na região medular estava presente, variando de discreta, moderada a intensa; caracterizando em muitos casos, uma linfadenite granulomatosa. Evidente plasmocitose também foi observada. A presença de formas amastigotas de Leishmania foi observada em 58 casos dos 120 estudados em cortes histológicos do linfonodo corados pela técnica de imunoistoquímica (Figura 3B). 
(A)
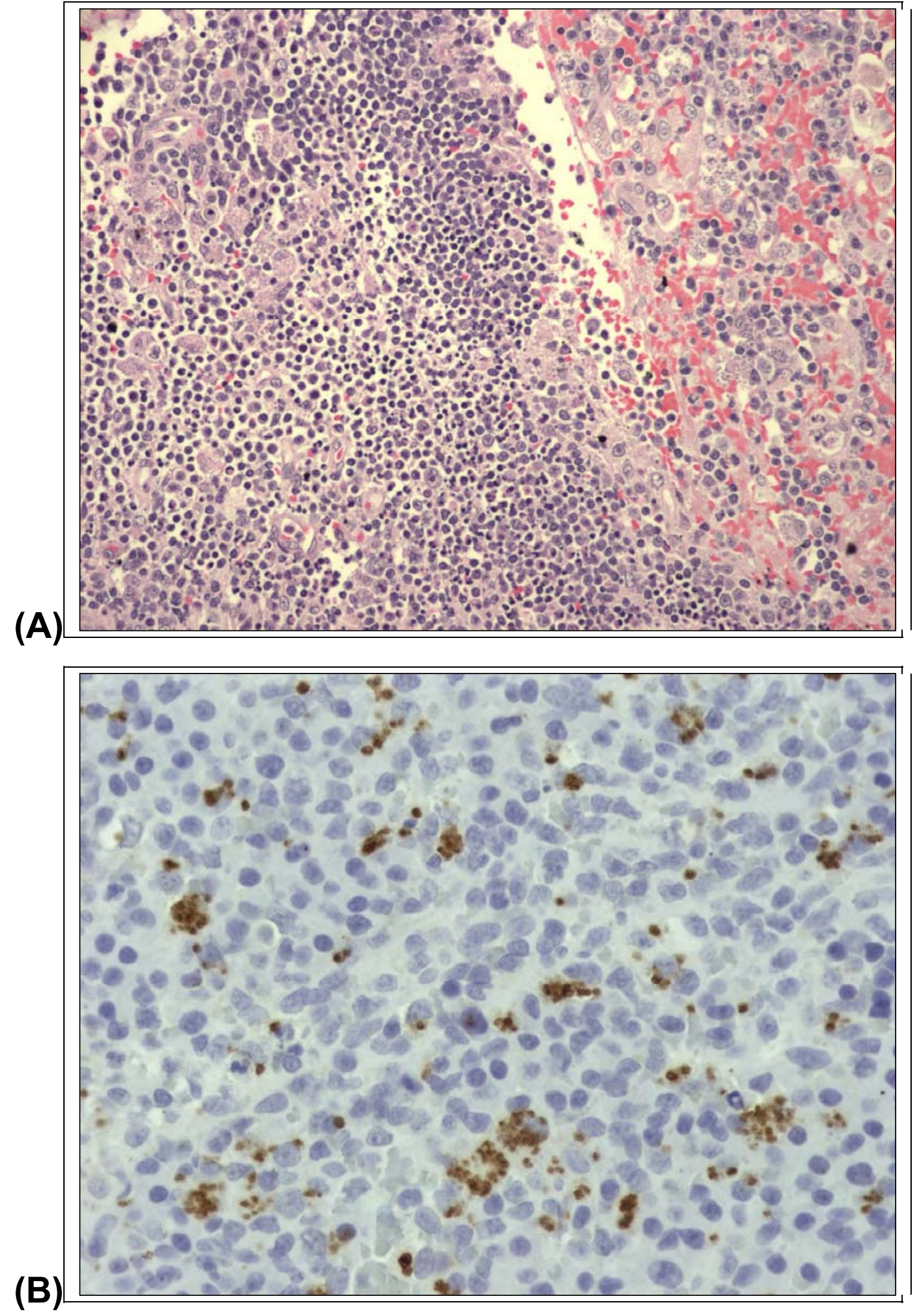

Figura 3 - A: Ativação folicular na área cortical e hiperplasia e hipertrofia de macrófagos em linfonodo de cão naturalmente infectado por L.(L.)chagasi (H\&E - objetiva 20X). B: Parasitismo em linfonodo de cão naturalmente infectado por L.(L.)chagasi (ABC - objetiva 40X) 


\subsubsection{Baço}

$\mathrm{Na}$ polpa branca foi observada hiperplasia folicular que variou de discreta, moderada a intensa; porém em alguns animais hipoplasia e até atrofia da polpa branca estavam presentes. As alterações histológicas da polpa vermelha se caracterizaram por hipertrofia e hiperplasia de macrófagos em caráter moderado a intenso. A presença de esboço granulomatoso assim como granulomas epiteliódes bem formados com células gigantes foi evidente na maioria dos casos (Figura 4A). Formas amastigotas de Leishmania foram observadas em 51 dos 120 casos estudados (Figura 4B).

(A)

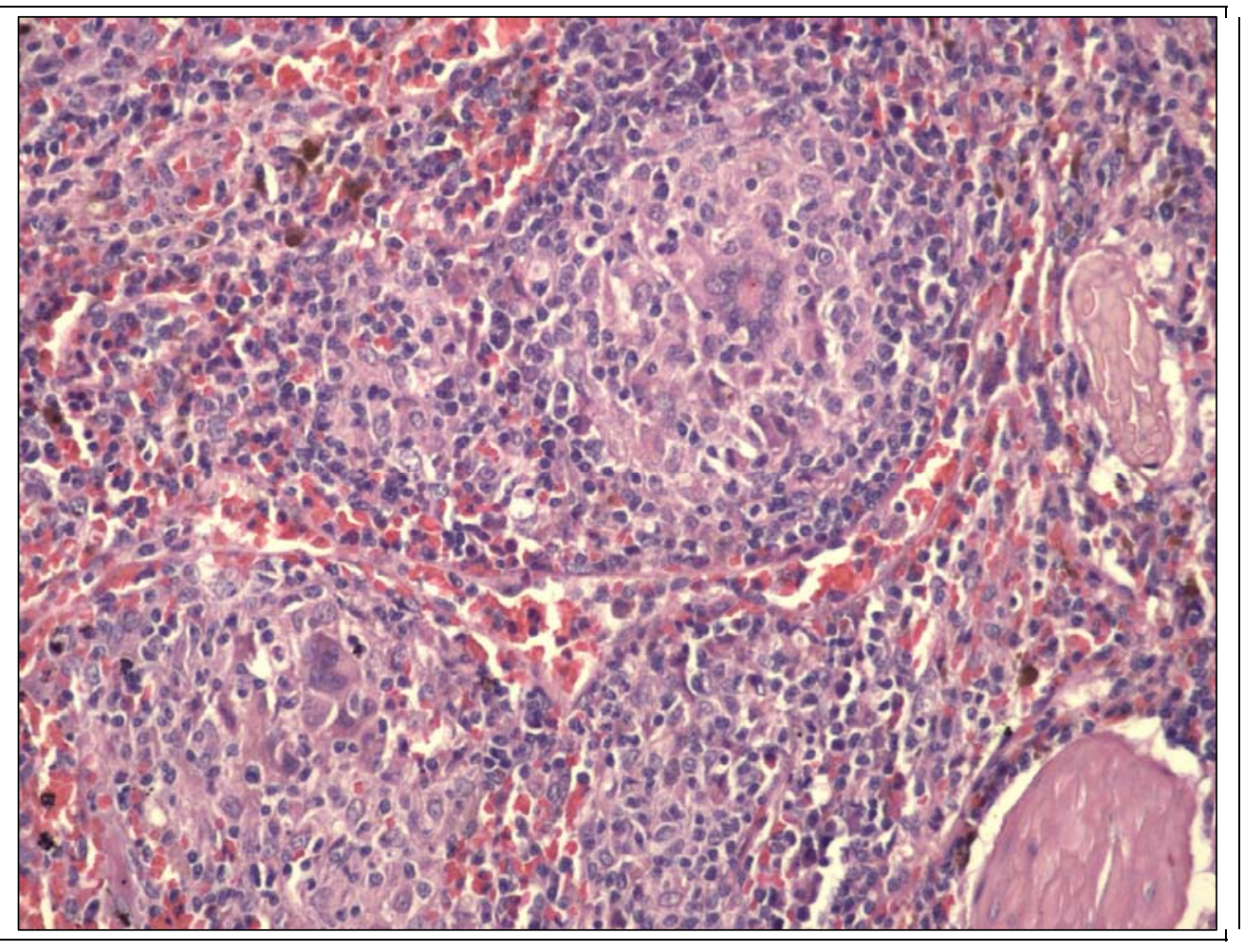




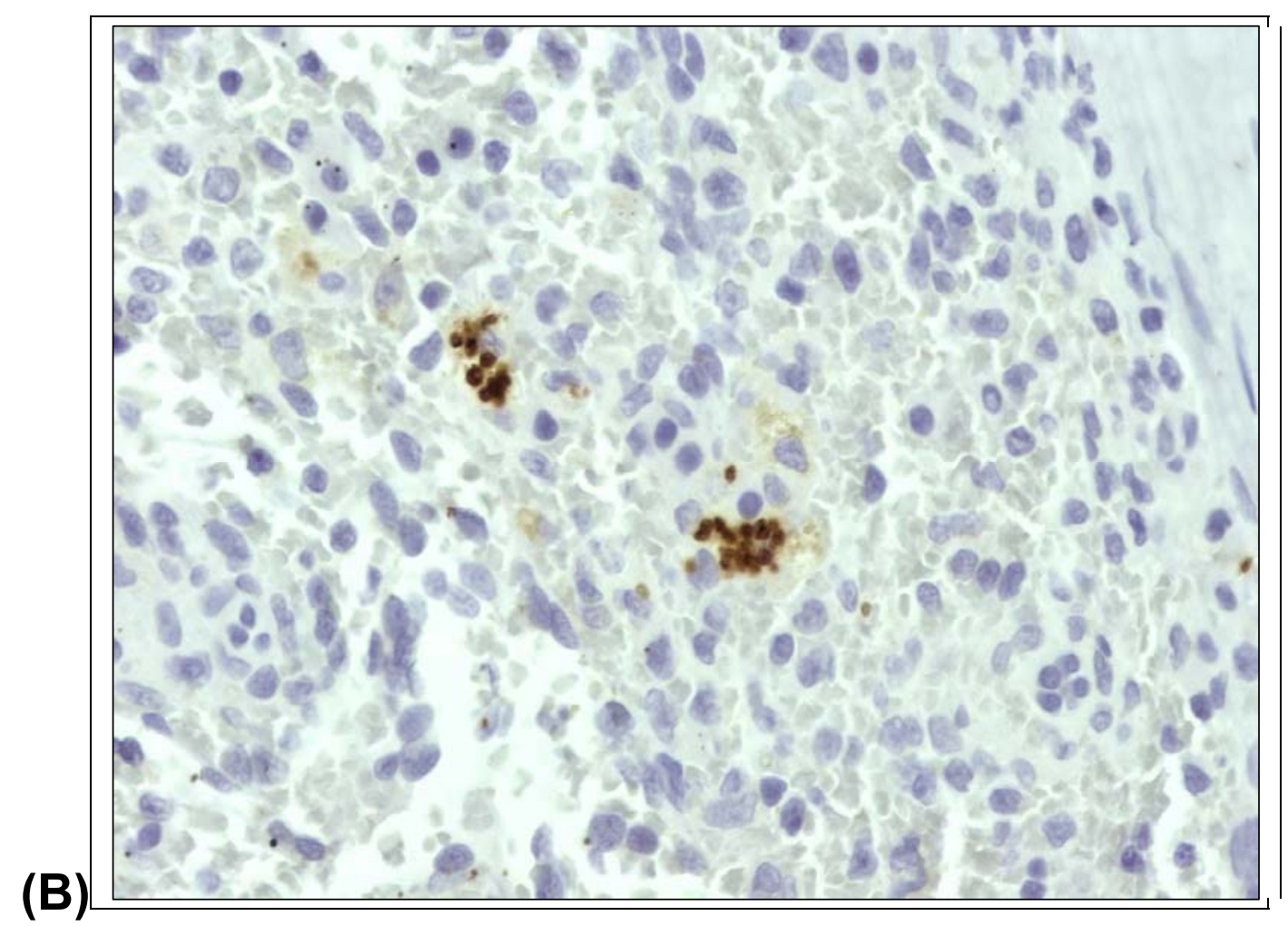

Figura 4 - A: Granuloma epitelióde com a presença de célula gigante ao centro em baço de cão naturalmente infectado por L.(L.)chagasi (H\&E - objetiva 20X). B: Parasitismo em baço de cão naturalmente infectado por L.(L.)chagasi (AB - objetiva 40X)

\subsection{Imunoistoquímica em tecido parafinado}

A reação de imunoistoquímica em tecido parafinado para detecção de macrófagos nos diferentes tecidos estudos, mostrou presença destas células em $100 \%$ dos casos em baço e linfonodo poplíteo; e em pele $90 \%$ dos animais estudados apresentavam células marcadas caracterizando macrófagos em infiltrado inflamatório, que variou de discreto a intenso (Figura 5). A reação de imunoistoquímica em tecido parafinado utilizando o anticorpo anti-CD3, mostrou a presença de células CD3+ em 100\% dos baços e linfonodos; e em 39\% das peles estudadas, variando também de intensidade discreta a intensa (Figura 6). 

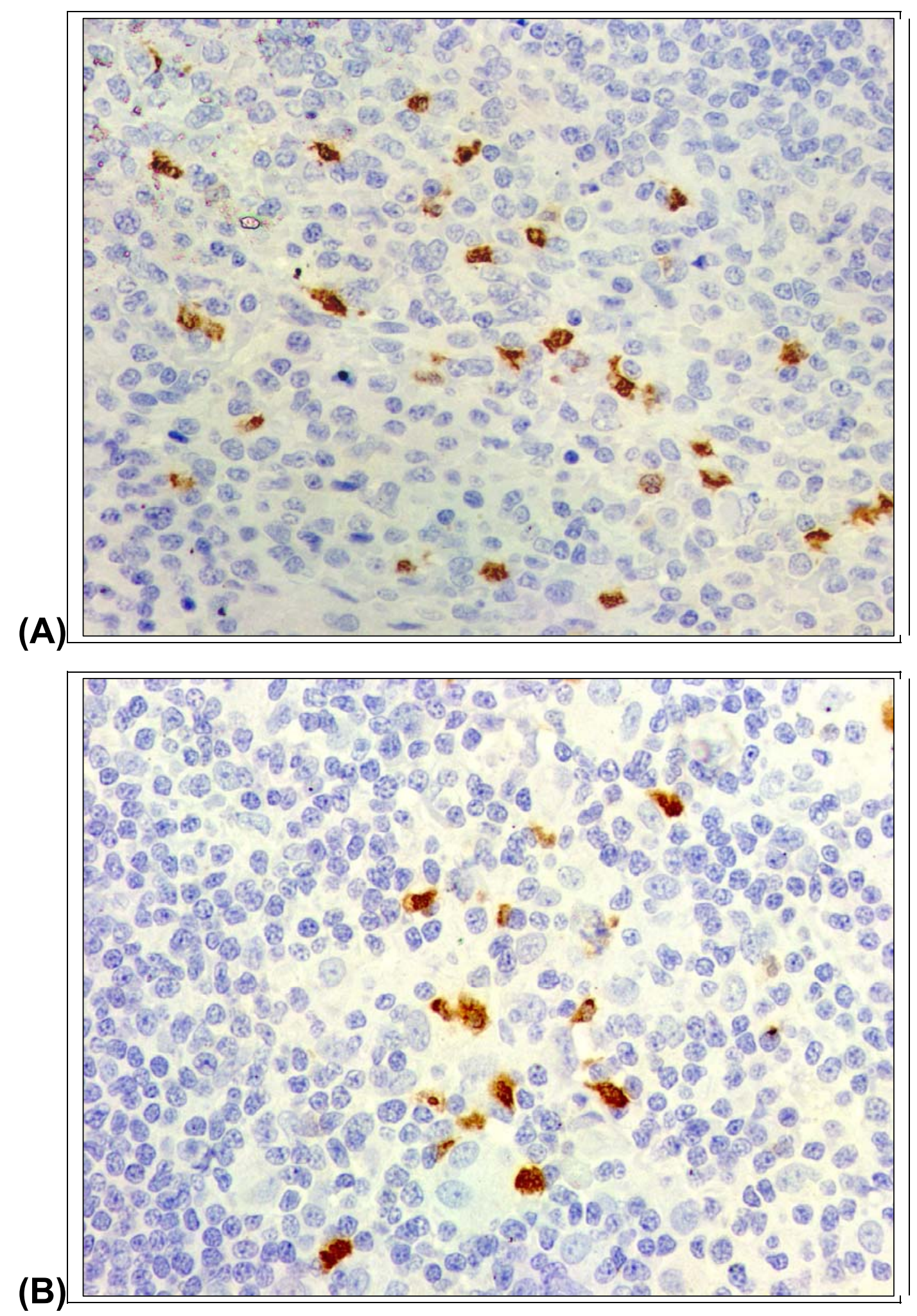


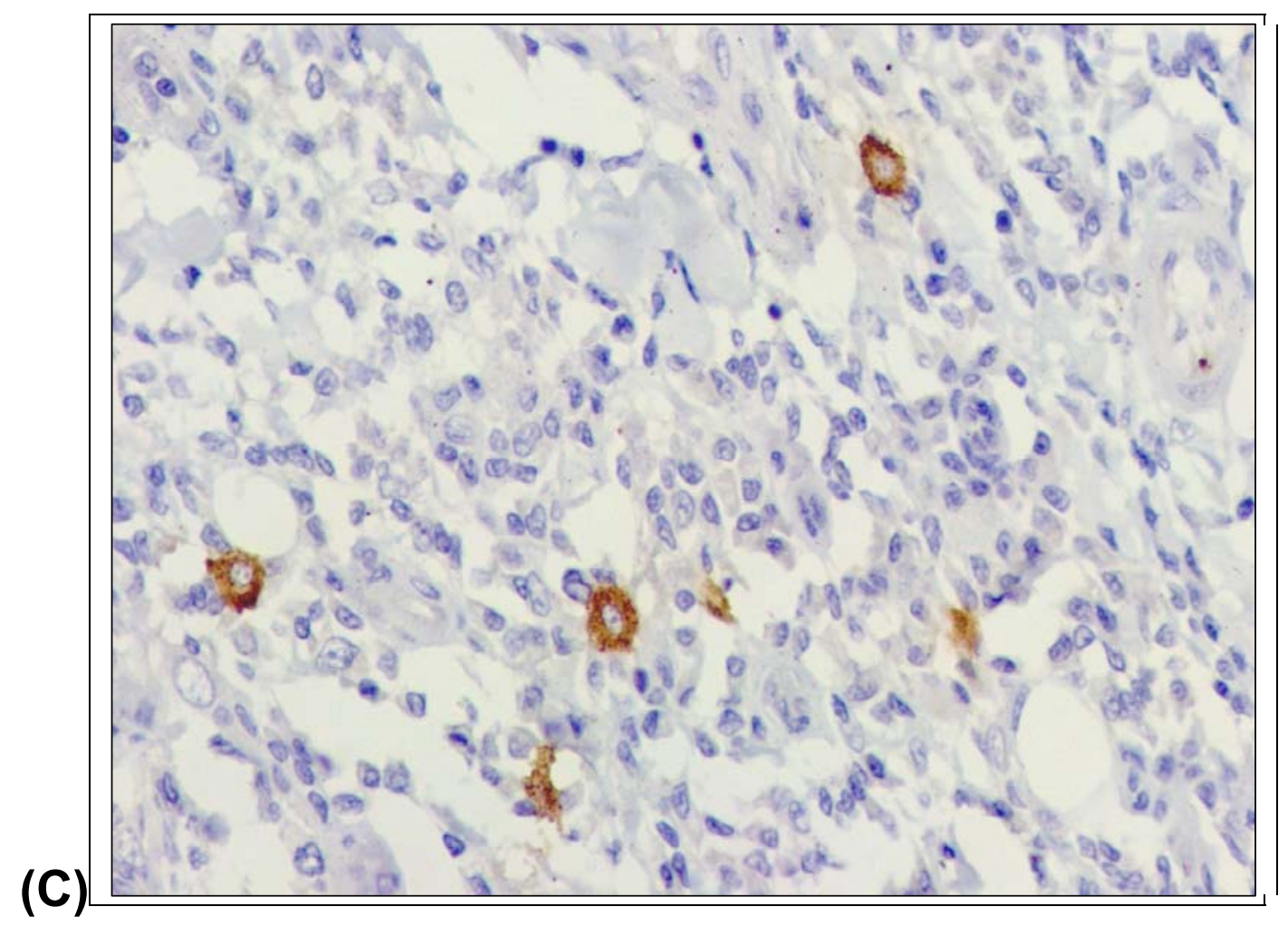

Figura 5 - Reação de imunoistoquímica demonstrando macrófagos em baço (A), linfonodo (B) e pele (C) de cão naturalmente infectado com L.(L.)chagasi (ABC - 40X)

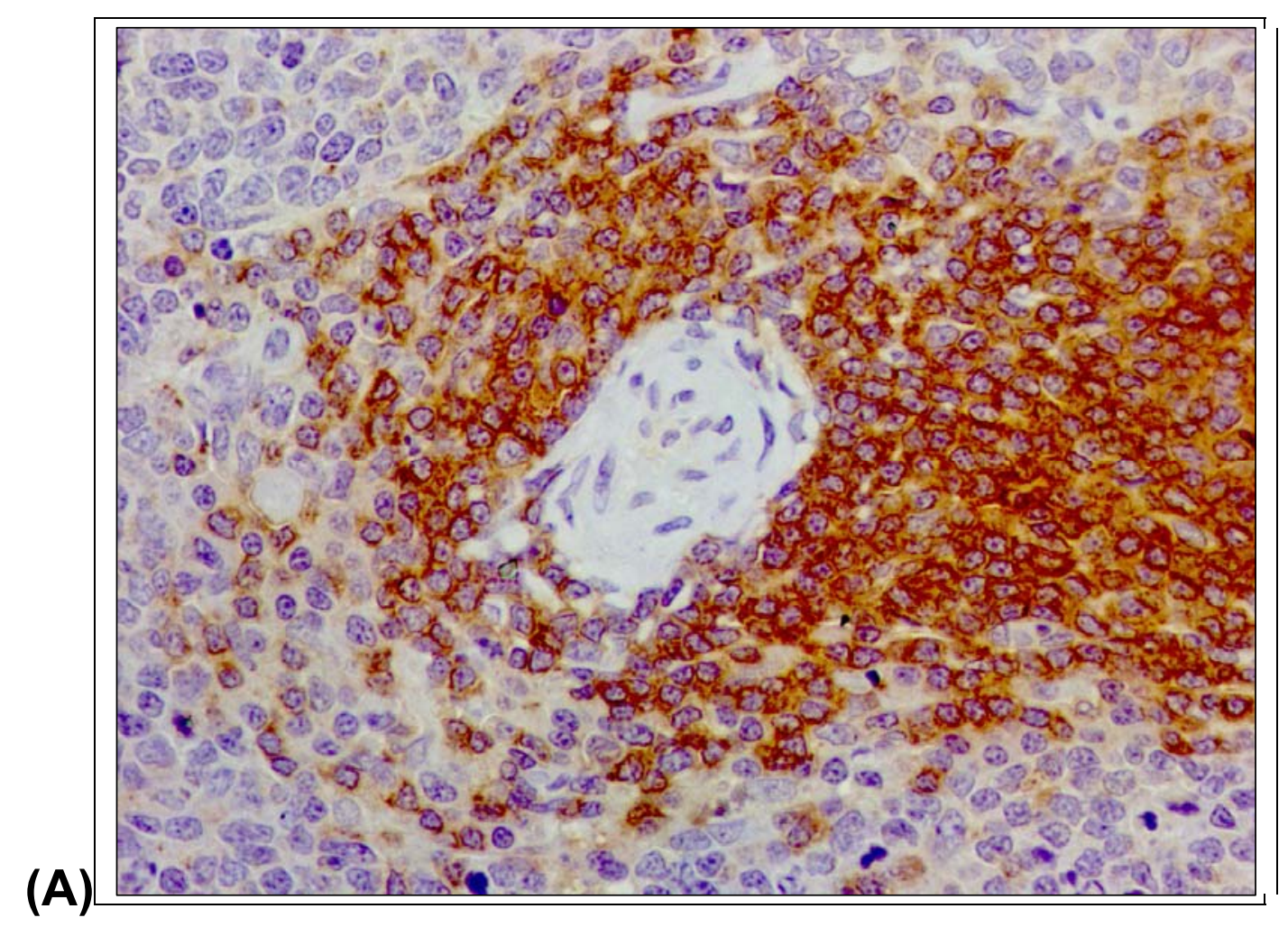



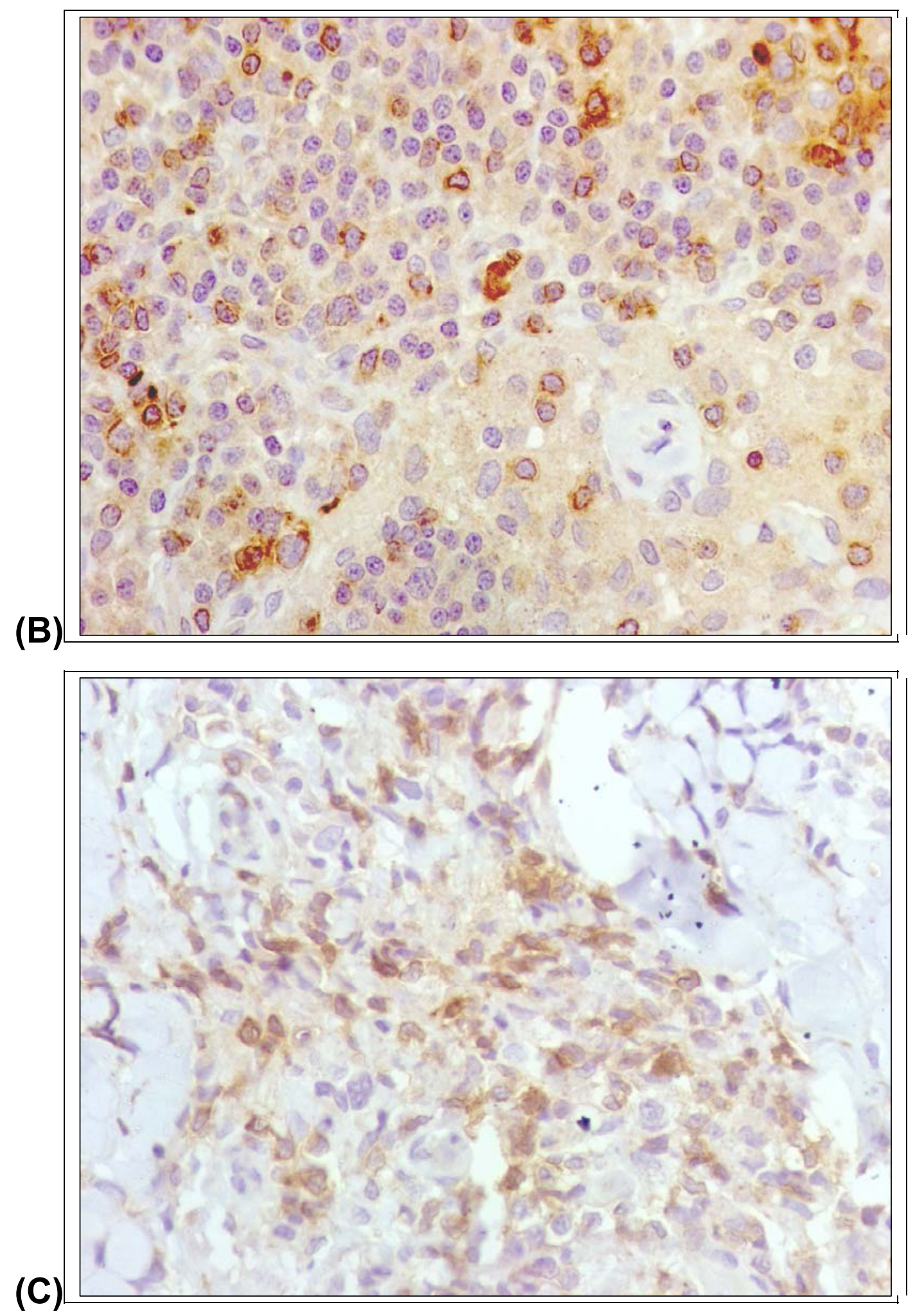

Figura 6 - Reação de imunoistoquímica demonstrando células CD3+ em baço $(A)$, linfonodo $(B)$ e pele (C) de cão naturalmente infectado com L.(L.)chagasi (ABC - 40X) 


\subsection{Correlação entre a imunomarcação de macrófagos e linfócitos com a carga parasitária}

Foram analisadas amostras de tecidos de baço, linfonodo e pele de cães de área endêmica para leishmaniose visceral, pela técnica de imunoistoquímica utilizando-se anticorpo policlonal anti-Leishmania para a detecção de formas amastigotas do parasito nos diferentes órgãos. Para a análise de células CD3+ nos mesmos tecidos foi utilizado o anticorpo anti-CD3 humano, que apresenta reatividade cruzada em tecido canino, molécula esta, presente na superfície de linfócitos.

Verificou-se maior quantidade de células CD3+ nas amostras de vísceras de animais negativos ou menos parasitados, porém este resultado não foi estatisticamente significante apesar de notarmos uma tendência de correlação inversamente proporcional, sugerindo que a presença de células CD3+ pode estar associada ao menor parasitismo visceral. Já na pele, houve uma associação direta entre número menor de células CD3+ e maior cargas parasitárias sugerindo que a resposta imune celular pode ser compartimentalizada na leishmaniose visceral canina.

A intensidade de marcação de macrófagos não teve correlação estatística com a carga parasitária mais foi possível observar que os animais assintomáticos e com menores cargas parasitárias apresentava um menor número de células marcadas. 


\subsection{Detecção de classes e subclasses de imunoglobulinas}

Os cães de área endêmica para leishmaniose visceral apresentaram níveis altos de IgG em relação aos cães controles de região não endêmica independentes de estarem parasitados ou não. Os maiores níveis de IgG total foram observados nos animais com diagnóstico parasitológico positivo quando comparado aos animais com diagnóstico parasitológico negativo $(p<0,05)$, porém nenhuma diferença foi encontrada entre os diferentes grupos clínicos, sintomático e assintomático (Figura $7 A)$.

A produção de IgE foi alta nos cães de área endêmica quando comparado aos controles de área não endêmica $(p<0,05)$. Houve diferença estatística significante entre os cães parasitados e não parasitados $(p<0,05)$, porém não houve diferença entre os grupos clínicos (Figura 7B).

Os níveis de lgG1 foram maiores nos cães de área endêmica em relação aos cães controles $(p<0,05)$, porém não houve diferenças entre os grupos clínicos ou entre animais parasitados ou não. Ao compararmos os níveis de lgG1 com a intensidade de parasitismo, observamos uma correlação positiva entre níveis mais elevados de IgG1 e intenso parasitismo $(p<0,05)$ (Figura $7 C)$.

Os níveis de IgG2 mostraram-se mais elevados nos cães de área endêmica independente do grupo clínico ou presença de parasitos quando comparados aos controles de área não endêmica $(p<0,05)$, sem diferença estatística entre os grupos clínicos ou quando comparados animais parasitados ou não (Figura 7D). 

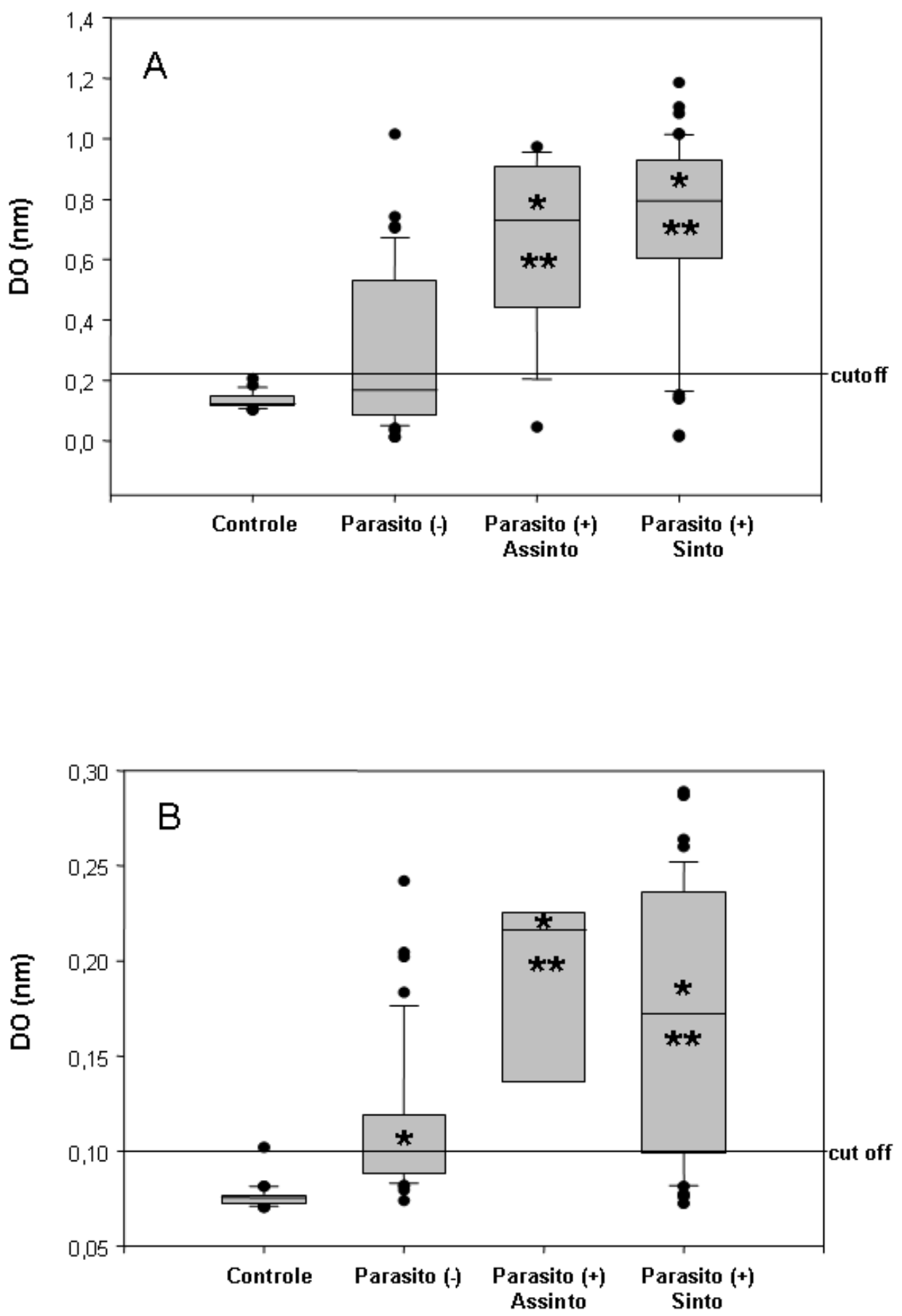

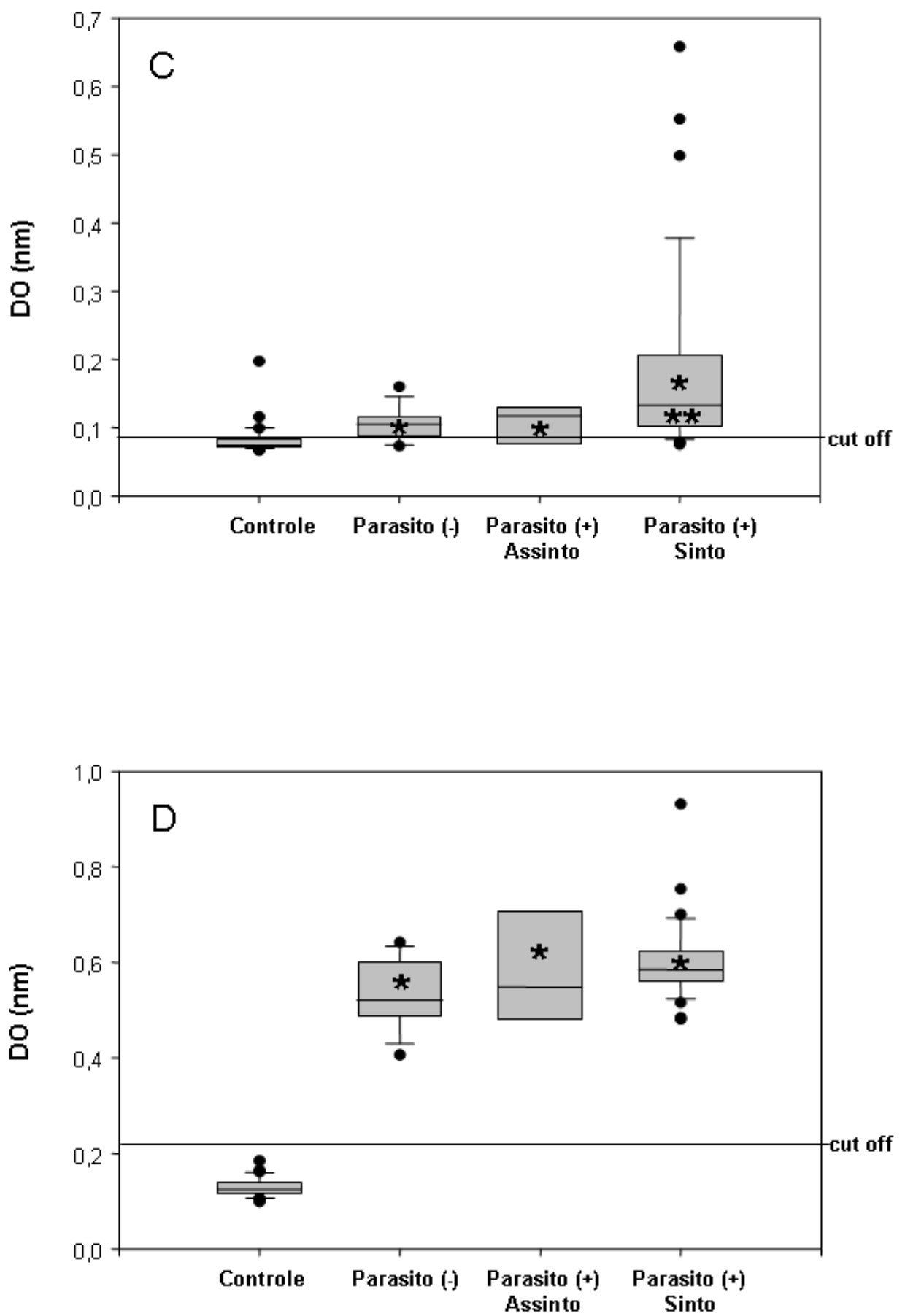

Figura 7 - Plotagem das densidades óticas $(\mathrm{nm})$ expressando a mediana e os percentis com barra de erro padrão. A - IgG, B - IgE, C - IgG1 e D - IgG2; onde * $P<0,05$ entre o controle, cães de área não endêmica para leishmaniose visceral e cães de área endêmica com e sem diagnóstico parasitológico positivo e sinais clínicos $e^{* *} p<0,05$ entre animais com diagnóstico parasitológico negativo e positivo sintomático e assintomático 


\subsection{Correlação entre parasitismo e classes e subclasses de imunoglobulinas}

A correlação entre as classes de imunoglobulinas estudadas e o parasitismo demonstrou uma correlação direta entre as intensidades de parasitismo nos diferentes tecidos estudados e os níveis de lgG total, mensurados através dos valores de densidade óptica, enquanto que uma correlação negativa foi encontrada quando comparada aos animais negativos ou com carga parasitária discreta $(p<0,05)$.

Os níveis de $\operatorname{lgE}$, quando correlacionados à carga parasitária dos diversos órgãos, apresentaram uma correlação positiva estatisticamente significante. A dosagem de IgE também foi capaz de distinguir os animais intensamente parasitados dos negativos ou discretamente parasitados $(p<0,05)$.

Com relação às subclasses, IgG1 apresentou uma correlação positiva entre parasitismo intenso e níveis mais elevados desta subclasse de imunoglobulina, enquanto que baixos valores estavam relacionados a discreto ou nulo parasitismo ( $p$ $<0,05)$. Os níveis de lgG2 moderados correlacionaram-se com níveis moderados de parasitismo em vísceras e níveis discretos com carga parasitária nula ou discreta em vísceras $(p<0,05)$. Não foi encontrada correlação entre níveis de lgG2 e parasitismo em pele.

\subsection{Xenodiagnóstico}

A média da porcentagem de fêmeas que apresentavam formas flageladas no tudo digestivo após 4 dias de alimentação em cães sintomáticos foi $27 \%$ enquanto em cães assintomáticos foi de $42 \%$. Quando a análise da infecção dos 
flebotomíneos foi feita pela técnica da PCR, observamos média de porcentagem de fêmeas positivas de $24 \%$ no grupo de animais sintomáticos e de $34 \%$ no grupo de animais assintomáticos. Estes resultados sugerem que cães assintomáticos em área endêmica para leishmaniose visceral devem ser considerados importante fonte de infecção para os flebotomíneos.

Em relação à resposta humoral, dos 40 animais utilizados no xenodiagnóstico, 37 apresentaram resultado positivo para lgG total, sendo $96 \%$ (23/24) no grupo sintomático e $87 \%$ (14/16) no grupo assintomático; e 33 mostraram reação de ELISA positiva para IgE, sendo 87\% (21/24) no grupo sintomático e $75 \%$ (12/16) no grupo assintomático. Quanto a positividade para as sub-classes de imunoglobulinas, IgG1 mostrou-se positiva em 62\% (15/24) dos sintomáticos e 44\% (7/16) dos assintomáticos, enquanto que lgG2 mostrou-se positiva em $87 \%(21 / 24)$ dos sintomáticos e $87 \%$ (14/16) dos assintomáticos. Dos 37 animais que mostraram ELISA positivo para $\operatorname{lgE}, 11$ apresentaram intenso parasitismo em víscera ou pele e 6 moderado.

A detecção de parasitos na pele por imunoistoquímica foi positiva em $54 \%$ (13/24) dos cães sintomáticos e em 31\% (5/16) dos assintomáticos. Macrófagos foram observados em $92 \%(22 / 24)$ das peles dos animais sintomáticos e em $75 \%$ (12/16) das peles dos animais assintomáticos, variando em caráter discreto a moderado. Em relação a expressão de células $T$ CD3+ na pele, reação positiva foi observada em 88\% (21/24) dos animais sintomáticos e em 50\% (8/16) dos assintomáticos. Dos 29 animais que apresentaram células T CD3+ na pele, 5 mostraram intenso parasitismo, 5 moderado, 5 discreto e 14 foram negativos. 0 número de células CD3+ parece ser inversamente proporcional ao número de parasitos na pele. Parasitos, macrófagos e células T CD3+ detectáveis por 
imunoistoquímica, em linfonodo foram positivos em 100\% (24/24) dos sintomáticos e em 100\% (16/16) dos assintomáticos. A detecção de parasitos em baço foi positiva em $88 \%(21 / 24)$ dos sintomáticos e em 31\% (5/16) dos assintomáticos; macrófagos e células CD3+ foram observados no baço em todos os animais dos diferentes grupos clínicos.

Os resultados referentes ao xenodiagnóstico mostraram que a resposta immune humoral e celular não tem correlação com a forma clínica da leishmaniose canina. A alta porcentagem de fêmeas de flebotomíneo infectadas que se alimentaram em cães assintomáticos mostram a importância destes animais na transmissibilidade do parasito para o vetor (Figura 8).

(A)

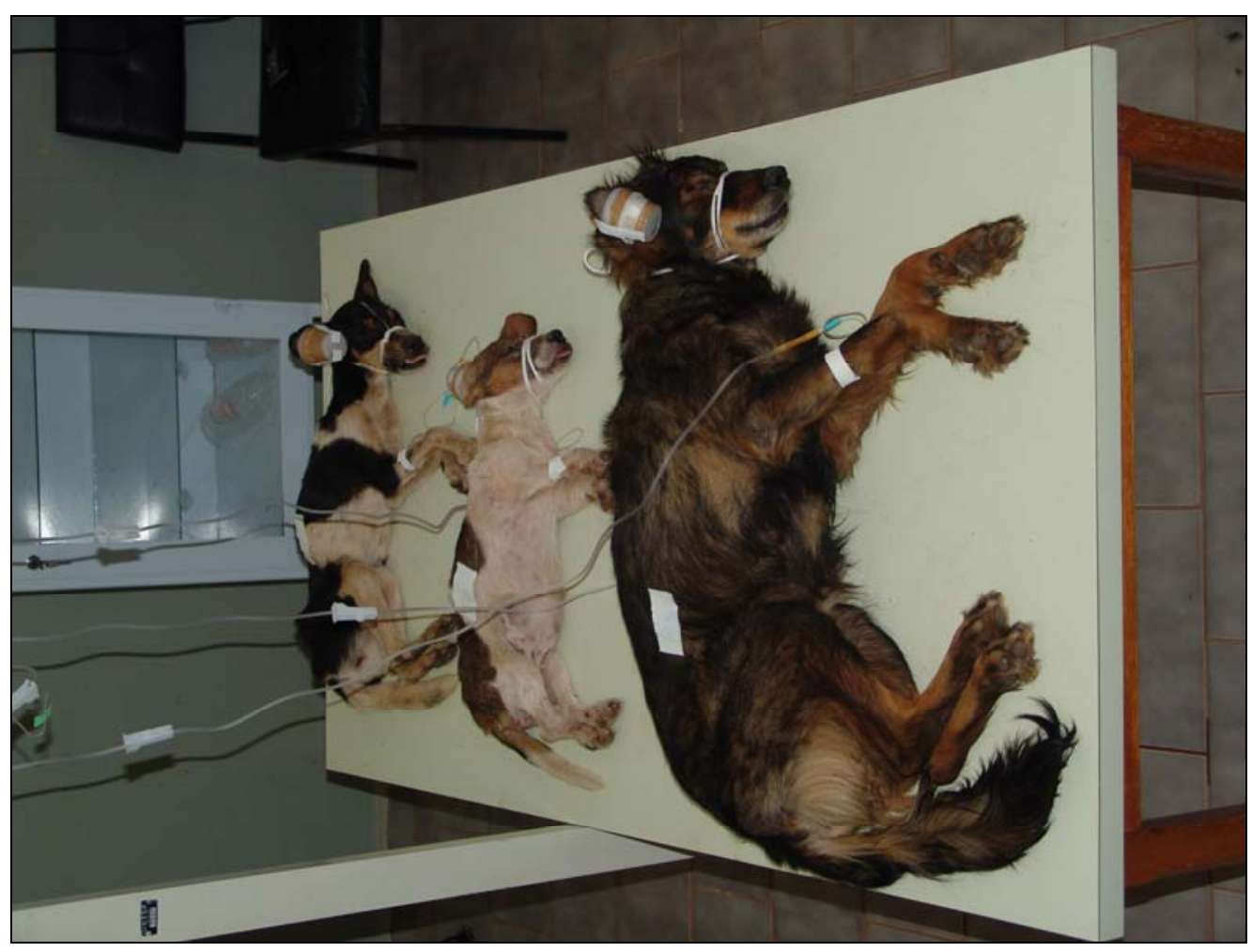


(B)
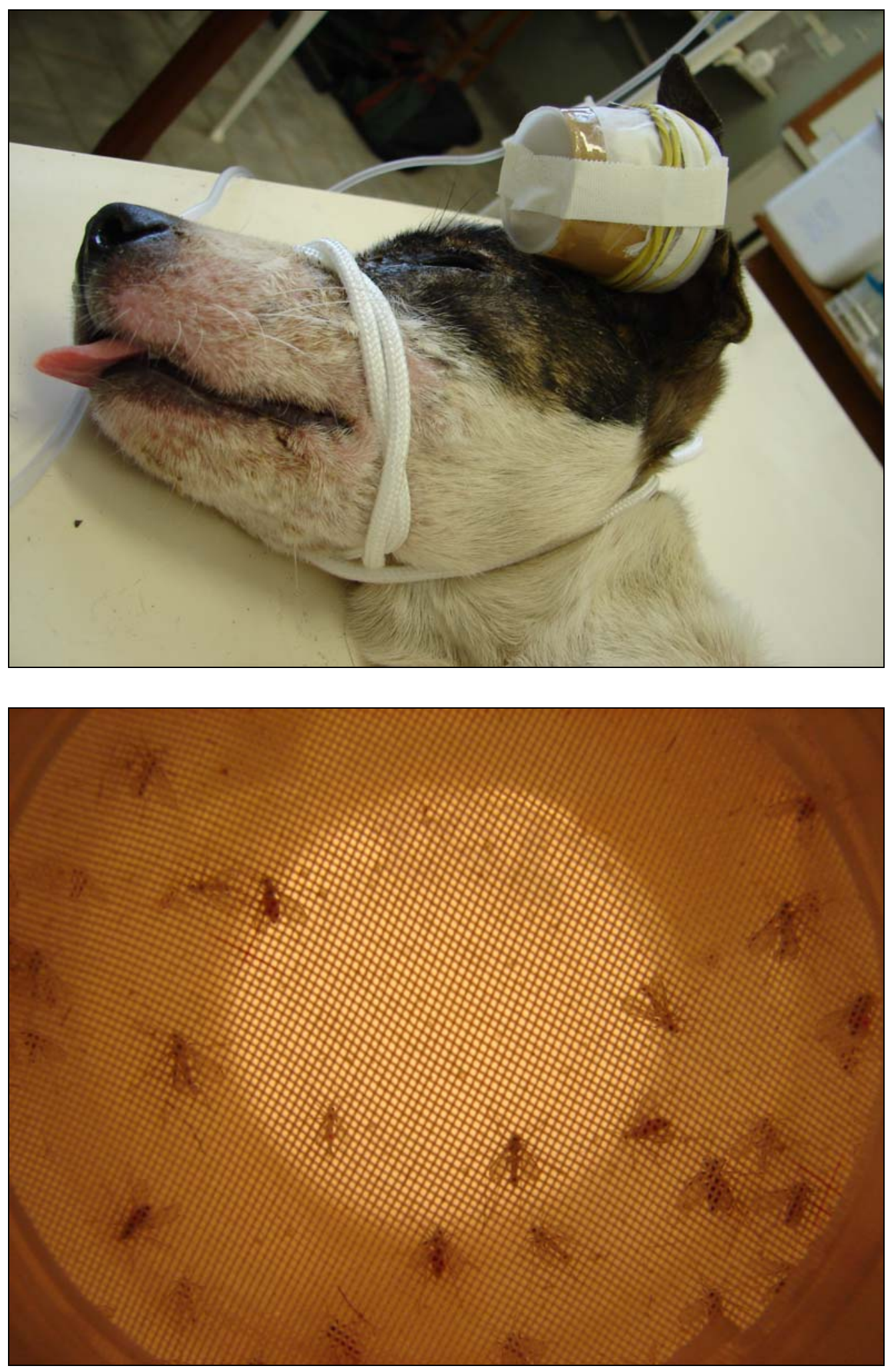

(C)

Figura 8 - Aspectos gerais da realização do xenodiagnóstico: (A) e (B) cães sedados e anestesiados durante o xenodiagnóstico, $(\mathrm{C})$ vetores após alimentação em cão naturalmente infectado 
DISCUSS ÃO 


\section{DISCUSSÃO}

A utilização de testes sorológicos para o diagnóstico de cães com leishmaniose tem sido empregada nos programas de controle da doença humana, porém estes testes baseiam-se na detecção de IgG total que não diferenciam cães infectados e não doentes de cães doentes ou vacinados. Desde modo, tem sido sacrificado indiscriminadamente todo cão soropositivo, medida onerosa que encontra resistência ética e sua eficiência tem sido questionada na redução da incidência da doença em humano (ASHFORD et al., 1995; MORENO; ALVAR, 2002). É possível que existam cães resistentes à doença e não transmissores, porém sorologicamente positivos, já que estão em área endêmica sendo, portanto, desafiados constantemente através de picadas de flebótomos infectados (GUARGA et al., 2000; TRAVI et al., 2001). Esse sacrifício em massa impediria uma seleção natural e como os animais são rapidamente repostos pela população, o ciclo da doença permanece e se dissemina para outras regiões (NEOGY et al., 1994; OLIVEIRAMENDES et al., 2003; FERNANDEZ-PEREZ et al., 2003). Desse modo, o perfil de imunoglobulinas bem como o estudo da imunidade celular poderia ajudar no prognóstico da doença através da sua associação com a produção de citocinas que indicaria o tipo de resposta imunológica presente no animal examinado.

A leishmaniose visceral humana é caracterizada por uma resposta imune do tipo Th-2 apresentando aumento da produção de IL-4, ativação policlonal de linfócitos B com intensa gamaglobulinemia e produção de IgE (ATTA et al., 1998). Contudo, existem apenas dois estudos com essa imunoglobulina em cães. Em relação às subclasses de $\lg G$, tanto em humanos quanto cães, os resultados são controversos: alguns estudos verificaram uma maior produção de $\lg G 1$ em animais 
sintomáticos e lgG2 estava presente em cães resistentes à infecção (DEPLAZES, 1995; NIETO, 1999; SOLANO-GALLEGO et al., 2001). Outros autores como Bourdoiser e colaboradores em 1997 e Vercammen e colaboradores em 2002 observaram a presença de IgG2 em maior grau nos animais sintomáticos.

Os objetivos desse trabalho foram investigar a imunidade humoral e celular em cães naturalmente infectados $L$. (L.) chagasi, através da avaliação de lgG, IgG1, IgG2 e IgE e macrófagos e linfócitos através de marcadores de superfície, respectivamente, e sua correlação com as formas clínicas da doença, bem como a carga parasitária em diversos tecidos (pele, linfonodo e baço) considerados importantes na patologia da doença (QUINNELL et al., 2003). Além disso, também investigamos a possível correlação entre estes aspectos e transmissão para o flebótomo-vetor.

O estudo da pele é importante, pois é a porta de entrada para o parasito e pode determinar o tipo de resposta imune gerada pelo hospedeiro e também é onde ocorre a infecção do flebótomo com as formas amastigotas (KEMP et al., 1996). Em nosso estudo verificamos presença de lesões caracterizadas por infiltrado inflamatório na derme, peri-anexal, formado principalmente por células mononucleares: macrófagos, linfócitos e plasmócitos. O infiltrado inflamatório variou de discreto a intenso, por vezes focal ou difuso, porém a análise estatística não demonstrou associações entre os achados anatomopatológicos e carga parasitária e/ou sintomatologia clínica, contudo existiu uma tendência de associação entre presença de granulomas e menor carga parasitária corroborando com os dados de Dos-Santos et al. (2004). Alguns estudos nesta área verificaram que pode haver uma relação entre a sintomatologia e o aspecto histológico da pele. Cães assintomáticos e/ou oligossintomáticos apresentaram número moderado de células 
de Langerhans, poucos queratinócitos expressando MHC-classe II e reduzido número de macrófagos. Enquanto que os animais com doença severa apresentavam grande quantidade de macrófagos com vacúolos repletos de parasitos, poucas células de Langerhans e queratinócitos sem expressão de MHC classe II representando um padrão de suscetibilidade (FONDEVILLA et al., 1997; SOLANOGALEGO et al., 2004). Em nosso estudo apesar de não haver significância estatística, observamos uma tendência semelhante, presença de maior número de células CD3+ com menor número de parasitos.

Muito pouco se sabe acerca de componentes e eventos ligados à eficiência ou a distúrbios inerentes à resposta imune in situ, nos órgãos-alvo da infecção canina por L. chagasi ou L. infantum (SANCHEZ et al., 2004). De forma semelhante ao observado em seres humanos e camundongos susceptíveis (KAYE et al., 2004), a esplenomegalia é um dos sinais mais freqüentemente descritos na LVC (SLAPPENDEL, 1988; CIARAMELLA et al., 1997; BLAVIER et al., 2001; TRAVI et al., 2001; SANCHEZ et al., 2004). As principais alterações histopatológicas no baço de cães portadores de infecção natural (TRYPHONAS et al., 1977; NATAMI et al., 2000; TAFURI et al., 2001) ou experimental (TAFURI et al., 1996) foram basicamente hiperplasia e hipertrofia do sistema mononuclear fagocitário. O estudo histopatológico realizado por Sanchez et al. (2004), no qual foram comparadas alterações hepáticas e esplênicas em cães naturalmente infectados por L. chagasi, demonstrou que havia evidências de respostas imunes distintas entre os órgãos analisados nos achados post-mortem. Em nossos estudos de tecido esplênico também verificamos a presença de hiperplasia folicular que variou de discreta, moderada a intensa; porém em alguns animais hipoplasia e até atrofia da polpa branca estavam presentes. As alterações histológicas da polpa vermelha se 
caracterizaram por hipertrofia e hiperplasia de macrófagos em caráter moderado a intenso com formas sugestivas de amastigotas de Leishmania, mas não houve associação estatística significante entre estes achados e a sintomatologia clínica desses animais e/ou carga parasitária. O mesmo ocorreu quando analisamos amostras de linfonodo poplíteo desses animais apesar das alterações encontradas; a área cortical e para-cortical dos linfonodos foi observada ativação folicular que variou de discreta a moderada. Hiperplasia e hipertrofia de macrófagos na região medular estava presente, variando de discreta, moderada a intensa; caracterizando em muitos casos, uma linfadenite granulomatosa. Com relação à resposta celular a presença de macrófagos e linfócitos nos tecidos estudados poderia associar-se a uma resposta contra o parasito, evidenciando uma resposta protetora, porém não obtivemos nenhuma correlação estatisticamente significante.

Com comercialização da vacina contra leishmaniose no Brasil é importante para a saúde pública dispor de métodos diagnósticos que possam assegurar que cães imunizados ou tratados não estejam transmitindo a doença para população humana (ALVAR et al., 1994; GUARGA et al., 2002). Atualmente isto só é possível através de xenodiagnóstico, um método de difícil execução. Neste estudo tentamos verificar um marcador humoral e celular que o substituísse, porém não obtivemos uma associação estatisticamente significante entre os marcadores estudados.

Nossos resultados demonstraram que os animais de área endêmica apresentaram altos níveis de $\lg$ e $\lg G 2$ independente de estar parasitado, demonstrando a exposição freqüente ao parasito leva ao desenvolvimento da resposta imune humoral independente do estado patológico. Em relação à lgG total, os resultados foram capazes de distinguir animais parasitados dos não parasitados, o que não ocorreu com lgG2. Cães parasitados em vísceras e pele tiveram altos 
níveis de lgG quando comparados a cães negativos no exame parasitológico. Altos níveis de lgG e IgG2 têm sido demonstrados em cães com leishmaniose visceral de curso natural ou experimental, sintomáticos e assintomáticos (SOLANO-GALLEGO et al., 2001; INIESTA et al., 2005), e altos níveis foram observados em cães assintomáticos (RODRÍGUES-CORTÉS et al., 2007). Almeida e colaboradores, em 2005, observaram uma forte correlação entre os títulos de anticorpos antiLeishmania lgG e lgG2 em cães sintomáticos, mas em nossos resultados não encontramos diferenças entre as classes e subclasses de imunoglobulinas quando correlacionadas ao estado clínico.

$\mathrm{Na}$ análise de anticorpo anti-Leishmania IgG1 obtivemos baixos níveis no método de ELISA utilizado, porém foi possível diferenciar animais de área endêmica para leishmaniose visceral dos de área não endêmica. No grupo de cães de área endêmica os altos níveis foram observados em cães sintomáticos com exame parasitológico positivo. Altos níveis de lgG1 tiveram uma correlação positiva com parasitismo intenso em víscera e pele. Iniesta et al., em 2005, relataram altos níveis de lgG1 apenas em cães que desenvolveram alterações patológicas, sugerindo a dosagem de IgG1 como um marcador em potencial de doença ativa em cães. A expressão da subclasse lgG1 cai rapidamente em cães responsivos ao tratamento anti-leishmania corroborando com seu uso como marcador de prognóstico (SOLANO-GALLEGO et al., 2001). Por outro lado, uma forte correlação foi encontrada entre IgG1 e cães assintomáticos por Reis et al. em 2006.

Nossos dados também detectaram baixos níveis de $\operatorname{lgE}$, porém com diferenças estatísticas significativas entre os grupos de cães de área endêmica e o grupo controle. Os animais com parasitismo intenso apresentaram níveis mais elevados de IgE. A correlação direta entre o parasitismo e níveis de lgE obteve as 
melhores associações quando comparados aos cães sintomáticos (INIESTA et al., 2005; REIS et al., 2006), levando à conclusão que a dosagem de IgE pode ser um bom marcador para identificação de cães transmissores da doença para o flebótomo. Almeida et al., em 2005, observaram que 33\% dos cães saudáveis de área endêmica estavam produzindo anticorpos anti-leishmania $\lg \mathrm{E}$ e concluiu que este achado poderia representar cães em início de infecção com perfil de susceptibilidade a leishmaniose visceral.

A infecção de cães por Leishmania parece ser independente da extensão das manifestações clínicas, sendo que cães assintomáticos podem ou não ser infectantes para os vetores flebotomíneos a depender do tempo de infecção e resposta imune do animal (TRAVI et al., 2001). Para propósitos epidemiológicos, é imprescindível uma estimativa precisa do número de portadores assintomáticos capazes de transmitir a doença. Isto diminuiria o número de cães eliminados e favoreceria a manutenção de cães resistentes à doença (MORENO; ALVAR, 2002). Desde modo, o perfil de imunoglobulinas poderia ser uma ferramenta de fácil execução para definir o prognóstico de cães infectados, pois está relacionada ao perfil de citocinas produzidas, podendo definir o padrão de resposta de linfócitos T CD4.

Nossos resultados nos levam a concluir que a maioria dos cães de área endêmica produz lgG e IgG2 independente do parasitismo ou sintomatologia, porém lgG1 e lgE estão correlacionados com carga parasitária e podem ser considerados bons marcadores de cães infectados com potencial de transmissão do parasito ao vetor. Com relação à resposta celular e transmissão para o vetor nossos resultados foram inconclusivos, mas acreditamos que estes estudos são de fundamental importância no conhecimento da doença, pois este conhecimento poderá servir 
como um pré-requisito para avaliar imunoterápicos e/ou vacinas analisando seu efeito na resposta imune canina e na capacidade de anular a transmissão do parasito ao vetor. 


\section{CONCLUSÕES}




\section{CONCLUSÕES}

I. Cães de área endêmica apresentaram altos níveis de $\lg G$ e $\lg G 2$ independente de estar parasitado.

II. A dosagem de lgG foi capaz de discernir animais parasitados dos não parasitados e o mesmo não ocorreu com lgG2.

III. Altos níveis de IgG1 e IgE correlacionaram-se com carga parasitária alta. E podem ser considerados bons marcadores de cães infectados provavelmente com potencial de transmissão para o vetor.

IV. Nenhuma das imunoglobulinas estudadas correlacionou-se com sintomatologia clínica.

V. Houve uma correlação inversa entre presença de marcação par CD3 e carga parasitária indicando a possível utilização de marcadores celulares para identificação da resposta imune celular.

VI. Fêmeas de flebótomos alimentadas em cães assintomáticos mostraram-se mais infectadas do que as alimentadas em animais sintomáticos evidenciando a importância desses animais no ciclo de transmissão. 
REFERÊNCIAS 


\section{REFERÊNCIAS}

ABRANCHES, P.; SILVA-PEREIRA, M. C. D.; CONCEIÇÃO-SILVA, F. M., SANTOSGOMES, G. M., JANZ, J, G. Canine leishmaniasis: pathological and ecological factors influencing transmission of infection. Journal of Parasitology, v. 77, n. 4, p. 557-561, 1991.

ALVAR, J., MOLINA, R., SANS-ANDRÉS, M., TESOURO, M., NIETO, J., VITUTIA, M., GONZALÉS, F., SANS-ANDRÉS, M. D., BOGGIO, J., RODRIGUEZ, F. Canine leishmaniasis: clinical, parasitological and entomological follow-up after

chemotherapy. Annals of Tropical Medicine and Parasitology, v. 88, n. 4, p. 371378, 1994.

AMUSATEGUI, I.; SÁINZ, A.; RODRÍGUEZ, F.; TESOURO, M. A. Tratamiento de la leishmaniosis canina. Medicina Veterinaria, v. 12, n. 5, p. 289-298, 1995.

ASHFORD, R.W.; DESJEUX, P.; RAADT, P. Estimation of risk of infection and number of cases of leishmaniasis. Parasitolology Today, v. 5, n. 3, p. 104-105, 1992.

ASHFORD, D. A.; BOZZA, M.; FREIRE, M.; MIRANDA, J. C.; SHERLOCK, I.; EULALIO, C.; LOPES, U.; FERNANDES, O.; DEGRAVE, W.; BAKKER JUNIOR, R. $\mathrm{H}$. Comparison of the polymerase chain reaction and serology for the detection of canine visceral leishmaniasis. American Journal of Tropical Medicine and Hygiene, v. 53, p. 251-255, 1995.

ASHFORD, D. A.; DAVID, J. R.; FREIRE, M.; DAVID, R.; SHERLOCK, I.; EULÁLIO, M.C.; SAMPAIO, D.P.; BADARO, R. Studies on control of visceral leishmaniasis: impact of dog control on canine and human visceral leishmaniasis in Jacobina, Bahia, Brazil. American Journal of Tropical Medicine and Hygiene, v. 59, n. 1, p. 53-57, 1998.

ASHFORD, R. W. The leishmaniases as emerging and reemerging zoonoses. International Journal of Parasitolology, v. 30, n.12-13,p.1269-1281, 2000.

ATTA, A. M.; DE OLIVEIRA, A.; CORREA, J.; ATTA, M. L. B.; ALMEIDA, R. P.; CARVALHO, E. M. Anti-Leishmania IgE antibodies: a marker of active disease in visceral leishmaniasis. American Journal of Tropical Medicine and Hygiene, v. 59, p. 426-430, 1998.

AZAZY, A. A.; CHANCE, M. L.; DEVANEY, E. A time-course study of circulating antigen and parasite-specific antibody in cotton rats infected with Leishmania donovani. Annals of Tropical Medicine and Parasitology, v. 91, n. 2, p. 153-162, 1997.

BADARO, R.; BENSON, D.; EULÁLIO, M. C., FREIRE, M., CUNHA, S., NETTO, E. M., PEDRAL-SAMPAIO, D., MADUREIRA, C., BURNS, J. M.,HOUGTON, R. L., DAVID, J. R., REED, S. J. rK39: A cloned antigen of Leishmania chagasi that preticts 
active visceral leishmaniasis. Journal of Infectious Diseases, n. 173, p. 758-761, 1996.

BARRAL, A.; COSTA, M. D.; BITTENCOURT, A. L.; BARRAL-NETTO, M.; CARVALHO, E. M. Polar and subpolar diffuse cutaneous leishmaniasis in Brazil: clinical and immunopathologic aspects. International Journal of Dermatology, $v$. 34, n. 7, p. $474-478,1995$.

BARRAL-NETTO, M.; BARRAL, A.; BROWNELL, C. E.; SKEIKY, Y. A.; ELLINGSWORTH, L. R.; TWARDZIK, D. R.; REED, S. G. Transforming growth factorbeta in leishmanial infection: a parasite escape mechanism. Science, v. 24, n. 257 , p. 545-548, 1992.

BARRAL-NETTO, M.; BARRAL, A.; BRODSKYN, C.; CARVALHO, E. M.; REED, S. G. Cytotoxicity in human mucosal and cutaneous leishmaniasis. Parasite Immunology, v. 17, n. 1, p. 21-28, 1995.

BATES, P. A. Transmission of Leishmania metacyclic promastigotes by phlebotomine sand flies. International Journal of Parasitology, v. 37, n. 10, p. 1097-1106, 2007.

BERRAHAL, F.; MARY, C.; ROZE, M., BERENGER, A., ESCOFFIER, K., LAMOUROUX, D., DUNAN, S. Canine leishmaniasis: identification of asymptomatic carries by polymerase chain reaction and immunobloting. American Journal Tropical Medicine Hygiene, v. 55, n. 3, p. 273-277, 1996.

BLAVIER, A.; KEROACK, S.; DENEROLLE, P.; GOY-THOLLOT, I.; CHABANNE, L.; CADORÉ, J. L.; BOURDOISEAU, G. Atypical forms of canine leishmaniosis. Veterinary Journal, v. 162, n. 2, p. 108-120, 2001.

BOGDAN, C.; GRESSNER, A.; SOLBACH, W.; ROLLINGHOFF, M. Invasion, control and persistence of Leismania parasites. Current Opinion in Immunology, v. 8, n. 5, p. 517-525, 1996.

BOGDAN, C.; ROLLINGHOFF, M. The immune response to Leishmania: mechanisms of parasite control and evasion. Internernational Journal of Parasitology, n. 28, p. 121-134, 1998.

BRAGA, M. D.; COÊLHO, I. C.; POMPEU, M. M.; EVANS, T. G.; MACAULLIFE, I. T.; TEIXEIRA, M. J.; LIMA, J. W. Control of canine visceral leishmaniasis: comparison of results from a rapid elimination program of serum-reactive dogs using an immunoenzyme assay and slower elimination of serum-reactive dogs using filter paper elution indirect immunofluorescence. Revista da Sociedade Brasileira de Medicina Tropical, v. 31, n. 5, p. 419-424, 1998.

BRITTINGAHAM, A.; MORRISON, J. C.; McMASTER, W. R.; McGWIRE, B. S.; CHANG, K. P.; MOSSER, D. M., . Role of the Leishmania surface gp63 in complement fixation, cell adhesion, resistance to complement-mediated lysis. Journal of Immunology., n. 155, p. 3102-3111, 1995. 
BURACCO, P.; ABATE, O.; GUGLIELMINO, R.; MORELLO, E. Osteomyelitis and arthrosynovitis associated with Leishmania donovani infection in a dog. Journal of Small Animal Practice, v. 38, n. 1, p. 29-30, 1997.

CABRERA, G. P.; DA SILVA, V. O.; DA COSTA, R. T.; REIS, A. B.; MAYRINK, W.; GENARO, O.;PALATNIK-DE-SOUSA, C. B. The fucose-mannose ligand-ELISA in the diagnosis and prognosis of canine visceral leishmaniasis in Brazil. American Journal of Tropical Medicine and Hygiene, v. 61, n. 2, p. 296-301, 1999.

CARVALHO, E. M.; JOHNSON, W. D.; BARRETO, E.; MARSDEN P.; COSTA, J. M. L.; STEVEN, R.; ROCHA, H. Cell mediated immunity in american cutaneous and mucosal leishmaniasis. Journal of Immunology, v. 135, n. 6, p. 4144-4148, 1985.

CHATTERJEE, M.; JAFFE, C. L.; SUNDAR, S.; BASU, D.; SEN, S.; MANDAL, C. Diagnostic and prognostic potential of a competitive enzyme-linked immunosorbent assay for leishmaniasis in India. Clinical and Diagnostic Laboratory Immunology, v.6, n. 4, p. 550-554, 1999.

CIARAMELLA, P.; OLIVA, G.; LUNA, R. D.; GRADONI, L.; AMBROSIO, R.; CORTESE, L.; SCALONE, A.; PERSECHINO, A. A retrospective clinical study of canine leishmaniasis in 150 dogs naturally infected by Leishmania infantum.

Veterinary Record, v. 141, n. 21, p. 539-543, 1997.

CORBETT, C. E.P.; LAURENTI, M. D.; NUNES, E. V.; GAMA-RODRIGUES, J. J.; OKUMURA, M. Cytokines and Chagas disease in mice. Revista do Hospital das Clinicas, Faculdade de Medicina, Universidade de São Paulo, v. 53, n. 1, p. 1-2, 1998.

CORBETT, C. E. P.; PAES, R. A.; LAURENTI, M. D.; ANDRADE JÚNIOR, H. F.; DUARTE, M. I. Histopathology of lymphoid organs in experimental leishmaniasis. International Journal of Experimental Pathology, v.73, n. 4, p. 417-433, 1992.

CORRENTI, M.; ORTEGA, G. Differences in the lymphoproliferative pattern to Leishmania mexicana antigens recognized by immunized and infected mice. Acta Tropica, v. 58, n. 3-4, p. 243-253, 1994.

COSTA, C. H. N.; PEREIRA, H. F.; ARAUJO, M. V. Epidemia de leishmaniose visceral no Estado do Piauí, Brasil. Revista de Saúde Pública, v. 24, n. 5, p. 361372, 1990.

CUNNINGHAM, A. C. Parasitic adaptive mechanisms in infection by Leishmania. Experimental and Molecular Pathology, v. 72, n. 2, p.132-141, 2002.

DEANE, L. M.; DEANE, M. P.; ALENCAR, J. E. Control of Phlebotomus longipalpis by DDT house spraying endemic foci of kala-azar in Ceará. Revista Brasileira de Malariolologia e Doenças Tropicais, v. 7, n. 1, p.131-141, 1955.

DOS-SANTOS, L. R.; BARROUIN-MELO, S. M.; CHANG, Y. F.; OLSEN, J.; MCDONOUGH, S. P.; ; QUIMBY, F.; DOS-SANTOS, W. L.; PONTES-DECARVALHO, L. C.; OLIVEIRA, G. G. Recombinant single-chain canine interleukin 12 
induces interferon gamma mRNA expression in peripheral blood mononuclear cells of dogs with visceral leishmaniasis. Veterinary Immunology and Immunopathology, v. 98, n. 1-2, p. 43-48, 2004.

DOS-SANTOS, W. L. C.; DAVID, J.; BADARÓ, R.; DE-FREITAS, L. A. R. Association between skin parasitism and a granulomatous inflamatory pattern in canine visceral leishmaniasis Parasitology Research, v. 94, p. 84-94, 2004.

DUARTE, M. I.; DA MATTA, V. L.; CORBETT, C. E. P.; LAURENTI, M. D.; CHEBABO, R.; GOTO H. Interstitial pneumonitis in human visceral leishmaniasis. Transactions of the Royal Society of Tropical Medicine and Hygiene, v. 83, n.1, p.73-76, 1989

DYE, C. The logic of visceral leishmaniasis control. American Journal of Tropical Medicine and Hygiene, v. 55, n. 2, p. 125-130, 1996.

FEITOSA, M. M.; IKEDA, F .A.; LUVIZOTTO, M. C. R.; PERRI, S. H. V. Aspectos clínicos de cães com leishmaniose visceral no município de Araçatuba - São Paulo (Brasil). Clínica Veterinária, v. 28, p. 36-44, 2000.

FERNANDEZ-PEREZ, F.J.; GÓMEZ-MUÑOZ, M. T.; MÉNDEZ, S.; ALUNDA, J. M. Leishmania-specific lymphoproliferative responses and lgG1/lgG2 immunodetection patterns by Western blot in asymptomatic, symptomatic and treated dogs. Acta Tropica, v.,86, p.,83-91, 2003.

FERRER, L.; AISA, M. J.; ROURA, X., PORTUS, M. Serological diagnosis and treatment of canine leishmaniasis. Veterinary Record, n.136, p. 514-516, 1995.

FONDEVILA, D.; VILAFRANCA, M.; FERRER, L. Epidermal immunocompetence in canine leishmaniasis. Veterinay Immunology and Immunopathology, v. 56, n. 3-4, p. 319-327,1997.

GARCÍA-ALONSO M.; BLANCO A.; REINA D.; SERRANO F. J.; ALONSO C.; NIETO C. G. Immunopathology of the uveitis in canine leishmaniasis. Parasite Immunology v. 18, n. 12, p. 617-623, 1996.

GAZZINELLI, R. T.; HIENY, S.; WYNN, T. A..; WOLF, S.; SHER, A. Interleukin 12 is required for the T-lymphocyte-independent induction of interferon gamma by an intracellular parasite and induces resistance in T-cell-deficient hosts. Proceedings of the National Academy of Sciences, v. 1, n. 90, p. 6115-6119, 1993.

GRIMALDI, G. Jr.; TESH, R. B. Leishmaniasis of the New World: Current concepts and implications for future research. Clininal Microbiology Reviews, v. 6, n. 3, p. 230-250, 1993.

GUARGA, J. L.; MORENO, J.; LUCIENTES, J.; GRACIA, M. J.; PERIBÁÑEZ, M. A.; ALVAR, J.; CASTILLO, J. A. Canine leishmaniasis transmission: higher infectivity amongst naturally infected dogs to sand flies is associated with lower proportions of $T$ helper cells. Research in Veterinary Science, v. 69, p. 249-253, 2000. 
GUARGA, J. L.; MORENO, J.; LUCIENTES, J.; GRACIA, M. J.; PERIBÁÑEZ, M. A.; CASTILLO, J. A. Evaluation of a specific immunochemotherapy for the treatment of canine visceral leishmaniasis. Veterinary Immunology and Immunopathology, $v$. 88, n. 1-2, p. 13-20, 2002.

HERMETO, M. V.; VIEIRA-DIAS, D.; GENARO, O.; DA COSTA, C. A.; TOLEDO, V.P.; MICHALICK, M. S.; TAFURI, W. L.; CHAVES, K. M.; MAYRINK, W. Delayed hypersensitivity skin-test using Leishvacin for epidemiological survey of canine cutaneous leishmaniasis in a rural area of Minas Gerais state, Brazil. Memórias do Instituto Oswaldo Cruz, v. 88, n. 4, p. 635-636, 1993.

HEUFLER, C.; KOCH, F.; STANZL, U.; TOPAR, G.; WYSOCKA, M.; TRINCHIERI, G.; ENK A.; STEINMAN, R. M.; ROMANI, N.; SCHULER, G. Interleukin-12 is produced by dendritic cells and mediates $T$ helper 1 developmentas well as interferon-gamma production by T helper 1 cells. European Journal of Immunology, v. 26, n. 3, p. 659-680, 1996.

HOMMEL, M.; JAFFE, C. L.; TRAVI, B.; MILON, G. Experimental models for leishmaniasis and for testing anti-leishmanial vaccines. Annals of Tropical Medicine and Parasitololy, v. 1, p. 55-73, 1995.

INIESTA, L.; GÁLLEGO, M.; PORTÚS, M., Immunoglobulins $\mathrm{G}$ and E responses in various stages of canine leishmaniosis. Veterinary Immunology and Immunopathology, v. 103, p. 77-81, 2005.

JAFFE, C. L. Recent trends in vaccine development and immunization. Clinical Dermatology, v. 17, n. 3, p. 339-344, 1999.

JARVIS, E. K.; RUTLEDGE, L. C. Laboratory observations on mating and leklike aggregations in Lutzomyia longipalpis (Diptera: Psychodidae). Journal of Medical Entomology, v. 29, p. 171-177, 1992.

KAMHAWI, S. Phlebotomine sand flies and Leishmania parasites: friends or foes? Trends in Parasitology, v. 22, n. 9, p. 439-445, 2006.

KAYE, P. M.; SVENSSON, M.; ATO, M.; MAROOF, A.; POLLEY, R.; STAGER, S.; ZUBAIRI, S.; ENGWERDA, C. R. The immunopathology of experimental visceral leishmaniasis. Immunological Reviews, v. 201, p. 239-253, 2004.

KEENAN, C. M.; HENDRICKS, L. D.; LIGHTNER, L.; WEBSTER, H. K.; JOHNSON, A. J. Visceral leishmaniasis in the German shepherd dog. I. Infection, clinical disease, and clinical pathology. Veterinary Pathology, v. 21, n. 1, p. 74-79, 1984.

KEMP, M.; THEANDER, T. G.; KHARAZMI, A. The contrasting roles of CD4+ T cells in intracellular infections in humans: leishmaniasis as an example. Immunology Today, v. 17, n.1, p.13-16, 1996.

KILLICK-KENDRICK, R. Phlebotomine vectors of the leishmaniases: a review. Medical and Veterinary Entomology, v. 4, p.1-24, 1990. 
KILLICK-KENDRICK, R.; MAROLI, M.; KILLICK-KENDRICK, M. Bibliography on the colonization of phlebotomine sandflies. Parasitologia, v. 33, p. 321-333, 1991.

KONTOS, V. J.; KOUTINAS, A. F. Old world canine leishmaniasis. Continuing Education Articles, v. 15, n. 7, p. 949-959, 1993.

LEMOS DE SOUZA, V.; ASCENÇÃO SOUZA, J.; CORREIA SILVA, T. M.; SAMPAIO TAVARES VERAS, P.; RODRIGUES DE-FREITAS, L. A. Different Leishmania species determine distinct profiles of immune and histopathological responses in CBA mice. Microbes and Infection, v. 2, n. 15, p. 1807-1815, 2000.

LIMA, H. C.; TIUS, R. G. Effects of sand fly vector saliva on development of cutaneous lesions and the immune response to Leishmania braziliensis in BALB/C mice. Infection and Immunity, v. 64, n.12, p. 5442-5445, 1996.

LIEW, F. Y.; LI, Y.; MILLOTT, S. Tumour necrosis factor (TNF-alpha) in leishmaniasis. II. TNF-alpha-induced macrophage leishmanicidal activity is mediated by nitric oxide from L-arginine. Immunology, v. 71, n. 4, p. 556-559, 1990.

LONGSTAFFE, J. A.; GUY, M. W. Canine leishmaniasis, United Kingtdom update. Journal of Small Animal Practice, v. 27, n. 10, p. 663-671, 1996

LOPEZ, R.; LUCENA, R.; NOVALES, M. Circulating immune complexes and renal fuction in canine leishmaniasis. Journal of Veterinary Medicine, v. 43, p. 469-474, 1996.

MANCIANTI, F.; PEDONESE, F.; POLI, A. Evaluation of dot enzyme-linked immunosorbent assay (dot-ELISA) for the serodiagnosis of canine leishmaniosis as compared with indirect immunofluorescence assay. Veterinary Parasitology, v. 65, n.1-2, p. 1-9, 1996.

MARZOCHI, M. C.; COUTINHO, S. G.; SABROZA, P. C. et al. Leishmaniose visceral canina no Rio de Janeiro- Brasil. Cadernos de Saúde Pública, v. 1, n. 4, p. 432446, 1985.

MATHIS, A.; DEPLAZES, P., PCR and in vitro cultivation for detection of Leishmania spp. In diagnostics samples from human and dogs. Journal of Clinical

Microbiology, v. 33, n. 5, p. 1145-1149, 1995.

MAURICIO, I. L.; HOWARD, M. K.; STOTHARD, J. R.; MILES, M. A. Genomic diversity in the Leishmania donovani complex. Parasitology, v. 119, n. 3, p. 237-246, 1999.

MAURÍCIO I. L.; STOTHARD J. R.; MILES M. A. The strange case of Leishmania chagasi. Parasitology Today, v. 16, n. 5, p. 188-189, 2000.

MAYRINK, W.; NASCIMENTO, E. Histopathology and immunocytochemical study of type 3 and type 4 complement receptors in the liver and spleen of dogs naturally and experimentally infected with Leishmania (Leishmania) chagasi. Revista do Instituto de Medicina Tropical, v. 38, n. 2, p. 81-89, 1996. 
MC CONVILLE, M. J.; BACIC, A.; MITCHELL, G. F.; HANDMAN, E. Lipophosphoglycan of Leishmania major that vaccinates against cutaneous leishmaniasis contain an alkylglycerophosphoinositol lipid anchor. Proccedings of the National Academy of Science, v. 84, p. 8941-8945, 1987.

MONTEIRO, P. S.; LACERDA, M. M.; ARIAS, J. R. Controle da leishmaniose visceral no Brasil. Revista Sociedade Brasileira de Medicina Tropical, v. 27, supl. III, p. 67-72, 1994.

MORENO, J.; ALVAR, J. Canine leishmaniasis: epidemiological risk and the experimental model. Trends Parasitolology, v. 18, p. 399-405, 2002.

MORENO, J.; NIETO, J.; CHAMIZO, C.; GONZÁLEZ, F.; BLANCO, F.; BARRER, D. C.; ALVA J. The immune response and PBMC subsets in canine visceral leishmaniasis before, and after, chemotherapy. Veterinary Immunology and Immunopatholology, v. 71, p.181-195, 1999.

MOSSALAYI, M. D.; AROK, M., MAZIER, D.; VINCENDEAU, P.; VOULDOUKIS, I. The human immune response during cutaneous leishmaniasis: NO problem.

Parasitology Today, v. 15, n. 8, p. 342-45, 1999.

NATAMI, A.; SAHIBI, H.; LASRI, S.; BOUDOUMA, M.; GUESSOUSS-IDRRISSI, N.; RHALEM, A. Serological, clinical and histopathological changes in naturally infected dogswith Leishmania infantum in the Khemisset province, Morocco. Veterinary Research, v. 31, n. 3, p. 355-363, 2000.

NEOGY, A. B.; VOULDOUKIS, I.; DA COSTA, J. M.; MONJOUR, L. Exploitation of parasite-derived antigen in therapeutic sucess against canine viceral leishmaniosis. Veterinary group of Lupino. Veterinary Parasitology, v. 54, p. 367-373, 1994.

NIETO, C. G.; GARCÍA-ALONSO, M.; REQUENA, J. M.; MIRÓN, C.; SOTO, M.; ALONSO, C.; NAVARRETE, I. Analysis of the humoral immune response against total and recombinant antigens of Leishmania infantum: correlation with disease progression in canine experimental leishmaniasis. Veterinary Immunology and Immunopathology, v. 67, n. 2, p.117-130, 1999.

NORONHA, F.; NUNES, A., C.; SOUZA, K., MELO, M. N.; PINTO, J.R. Differential sensitivity of New world Leishmania spp. Promastigotes to complement-mediated lysis: correlation with the expression of three parasite polypeptides. Acta Tropica, $\mathrm{n}$. 69, p. 17-29, 1998.

OLIVEIRA-MENDES, C.; PARAGUAI DE SOUZA, E.; BORJA-CABRERA, G. P.; MARIA MELO BATISTA, L.; APARECIDA DOS SANTOS, M.; ELMER PARRA, L.; MEN,Z I.; PALATINIK, M.; PALATINIK DE SOUSA, C. B. IgG1/lgG2 antibody dichotomy in sera of vaccinated or naturally infected dogs with visceral leishmaniasis. Vaccine, v. 21, p. 2589-2597, 2003. 
PARANHOS-SILVA, M.; FREITAS, L. A. R.; SANTOS, W. C.; GRIMALDI JR, G.; PONTES-DE-CARVALHO, L. C.; OLIVEIRA-DOS-SANTOS, A. J. A cross-sectional serodiagnostic survey of canine leishmaniasis due to $L$. chagasi. American Journal of Tropical Medicine and Hygiene, v. 55, n. 1, p. 39-44, 1996.

PINELLI, E.; GONZALO, R. M.; BOOG, C. J.; RUTTEN, V. P.; GEBHARD, D.; DEL REAL, G.; RUITENBERG, E. J. Leishmania infantum-specific T cell lines derived from asymptomatic dogs that lyse infected macrophages in a major histocompatibility complex-restricted manner. European Journal of Immunology, v. 6, p. 1594-1600, 1995.

PINELLI, E.; VAN DER KAAIJ, S. Y.; SLAPPENDEL, R.; FRAGIO, C.; RUITENBERG, E.J.; BERNADINA, W.; RUTTEN, V.P. Detection of canine cytokine gene expression by reverse transcription-polymerase chain reaction. Veterinary Immunology and Immunopathology, v. 69,n. 2-4, p. 121-126, 1999.

PINTO, A. R. et al. Identification of a $30 \mathrm{kDa}$ antigen from Leishmania (L.) chagasi amastigotes implicated in protective cellular responses in a murine model.

International Journal of Parasitology., n. 30, p. 599-607, 2000.

POLI, A.; ABRAMO, F.; MANCIANTI, F.; NIGRO, M.; PIERI, S.; BIONDA, A. Renal involvement in canine leishmaniasis. A light-microscopic, immunohistochemical and electron-microscopic study. Nephron, v. 57, n. 4, p. 444-452, 1991.

POZIO, E.; GRANDONI, L.; BETTINI, S.; GRANICIA, M. Leishmaniasis in Tuscany (Italy): IV Canine leishmaniasis in the focus of Monte Argentario. Acta Tropica, v. 38, p. 383-393, 1981.

PRASAD, L. S. Kala azar. Indian Journal of Pediatry, v. 66, n. 4, p. 539-546, 1999.

QUIJADA, L.; REQUENA, J. M.; SOTO, M.; GÓMEZ, L. C.; GUZMAN, F.; PATARROYO, M. E.; ALONSO, C. Mapping of the linear antigenic determinants of the Leishmania infantum hsp70 recognized by leishmaniasis sera. Immunology Letters, v. 52, n. 2-3, p. 73-79, 1996.

QUINNELL, R. J.; COURTENAY, O.; GARCEZ, M. L.; KAYE, P. M.; SHAW, M. A.; DYE, C.; DAY, M. J. IgG subclass responses in a longitudinal study of canine visceral leishmaniasis. Veterinary Immunology and Immunopathology, v. 91, p.161-168, 2003.

QUINNELL, R. J.; COURTENAY, O.; SHAW, M. A.; DAY, M. J.; GARCEZ, L. M.; DYE, C.; KAYE, P. M. Tissue cytokine responses in canine visceral leishmaniasis. Journal of Infectious Diseases, v. 183, n. 9, p. 1421-1424, 2001.

REIS, A. B.; TEIXEIRA-CARVALHO, A.; VALE, A. M.; MARQUES, M. J.; GIUNCHETTI, R. C.; MAYRINK, W.; GUERRA, L. L.; ANDRADE, R. A.; CORREAOLIVEIRA, R.; MARTINS-FILHO, O. A. Isotype patterns of immunoglobulins: Hallmarks for clinical status and tissue parasite density in brazilian dogs naturally infected by Leishmania (Leishmania) chagasi. Veterinary Immunology and Immunopathology, v. 112, p.102-116, 2006. 
REITHINGER R.; DAVIES C. R. Canine leishmaniasis: novel strategies for control. Trends Parasitology, v. 18, n. 7, p. 289-290, 2002.

REITHINGER, R.; DAVIES, C. R. Is the domestic dog (Canis familiaris) a reservoir host of American cutaneous leishmaniasis? A critical review of the current evidence. American Journal of Tropical Medicine and Hygiene, v. 61, n. 4, p. 530-541, 1999.

RHALEM, A.; SAHIBI, H.; GUESSOUS-IDRISSI, N.; LASRI, S.; NATAMI, A.; RIYAD, M.; BERRAG, B. Immune response against Leishmania antigens in dogs naturally and experimentally infected with Leishmania infantum. Veterinary Parasitolology, v. 81, n. 3, p. 173-184, 1999.

RHALEM, A.; SAHIBI, H.; LASRI, S.; JAFFE, C. L. Analysis of immune responses in dogs with canine visceral leishmaniasis before, and after, drug treatment. Veterinary Immunology and Immunopathology, v. 71, n. 1, p. 69-76, 1999.

RODRÍGUEZ-CORTÉS, A.; OJEDA, A.; LÓPEZ-FUERTES, L.; TIMÓN, M.; ALTET, L.; SOLANO-GALLEGO, L.; SÁNCHEZ-ROBERT, E.; FRANCINO, O.; ALBEROLA $\mathrm{J}$. A long term experimental study of canine visceral leishmaniasis. International Journal of Parasitology, v. 37, p. 683-693, 2007.

ROGERS, M. E.; ILG, T.; NIKOLAEV, A. V.; FERGUSON, M. A.; BATES, P. A. Transmission of cutaneous leishmaniasis by sand flies is enhanced by regurgitation of fPPG. Nature, v. 430, n. 6998, p. 463-467, 2004.

ROURA, X.; FONDEVILA, D.; SÁNCHEZ, A.; FERRER, L. Detection of Leishmania infection in paraffin-embedded skin biopsies of dogs using polymerase chain reaction. Journal of Veterinary Diagnostic Investigation, v. 11, n. 4, p. 385-387, 1999.

SANCHEZ, M. A.; DIAZ, N. L.; ZERPA, O.; NEGRON, E.; CONVIT, J.; TAPIA, F. J. Organ-specific immunity in canine visceral leishmaniasis: analysis of symptomatic and asymptomatic dogs naturally infected with Leishmania chagasi. American Journal of Tropical Medicine and Hygiene, v. 70, n. 6, p. 618-624, 2004.

SANTA ROSA, I. C. A. Perfil epidemiológico dos casos de leishmaniose tegumentar americana notificados na região metropolitana de Belo Horizonte. 1997. 87 f. Dissertação (Mestrado em Epidemiologia)- Escola de Medicina Veterinária, Universidade Federal de Minas Gerais, Minas Gerais, 1997.

SÃO PAULO (Estado). Secretaria de Estado da Saúde. Leishmaniose Visceral Americana. Disponível em:<www.sucen.sp.gov.br/doença/leish visc $>$. Acesso em: 27 jan. 2007.

SCHILLING, S.; GLAICHENHAUS, N. T cell that react to the immunodominant Leishmania major LACK antigen prevent early dissemination of the parasite in susceptible BALB/c mice. Infection and Immunity, v. 69, n. 2, p. 1212-1214, 2001. 
SHERLOCK, I. A.; MAIA, H.; DIAS-LIMA, A. G. Resultados preliminares de um projeto sobre a ecologia dos flebotomíneos vetores de leishmaniose tegumentar no Estado da Bahia. Revista Sociedade Brasileira Medicina Tropical, v. 29, n. 2, p. 207-214, 1996.

SHERLOCK, I. A. Ecological interactions of visceral leishmaniasis in the State of Bahia, Brazil. Memórias Instituto Oswaldo Cruz, v. 91, n. 6, p. 671-683, 1996.

SHERLOCK, I. A.; MAIA, H.; DIAS-LIMA, A. G. Resultados preliminares de um projeto sobre a ecologia dos flebotomíneos vetores de leishmaniose tegumentar no Estado da Bahia. Revista Sociedade Brasileira Medicina Tropical, v. 29, n. 2, p. 207-214, 1996.

SILVA, D. A.; CABRAL, D. D.; BERNARDINA, B. L.; SOUZA, M. A.; MINEO, J. R. Detection of Toxoplasma gondii-specific antibodies in dogs. A comparative study of immunoenzymatic, immunofluorescent and haemagglutination titers. Memórias do Instituto Oswaldo Cruz, v. 92, n. 6,p.785-789, 1997.

SLAPPENDEL, R. J. Canine leishmaniasis. A review based on 95 cases in The Netherlands. Veterinary Quarterly, v. 10, n.1, p. 1-16, 1988.

SLAPPENDEL, R. J.; GREENE, C. E. Leishmaniasis. In: GREENE, C.E. Infectious diseases of the dog and cat. 3th ed. Philadelphia, WB Saunders Co, 1990, pp769777.

SOLANO-GALLEGO, L.; FERNÁNDEZ-BELLON, H.; MORELL, P.; FONDEVILA, D.; ALBEROLA, J.; RAMIS, A.; FERRER, L. Histological and immunohistochemical study of clinically normal skin of Leishmania infantum-infected dogs. Journal of Comparative Patholology, v. 130, n. 1, p. 7-12, 2004.

SOLANO-GALLEGO, L.; RIERA, C.; ROURA, X.; INIESTA, L.; GALLEGO, M.; VALLADARES, J. E.; FISA, R.; CASTILLEJO, S.; ALBEROLA, J.; FERRER, L.; ARBOIX, M.; PORTÚS, M. Leishmania infantum-specific IgG, IgG1 and IgG2 antibody responses in healthy and ill dogs from endemic areas. Evolution in the course of infection and after treatment. Veterinary Parasitology, v. 96, p. 265-276, 2001.

SOUZA, V. L., SOUZA, J. A., SILVA, T. C., VERAS, P. T., FREITAS, L. A. Different Leishmania species determine distinct profiles of immune and histopathological response in CBA mice. Microbes and Infection, v. 2, p. 1807-1815, 2000

TAFURI, W. L.; DE OLIVEIRA, M. R.; MELO, M. N.; TAFURI, W. L. Canine visceral leishmaniosis: a remarkable histopathological picture of one case reported from Brazil. Veterinary Parasitolology, v. 96, n. 3, p. 203-212, 2001.

TAFURI, W. L.; MICHALICK, M. S.; DIAS, M.; GENARO, O.; LEITE, V. H.; BARBOSA,A. J.; BAMBIRRA, E. A.; DA COSTA, C. A.; MELO, M. N.; MAYRINK, W. Optical and electron microscopic study of the kidney of dogs naturally and 
experimentally infected with Leishmania (Leishmania) chagasi. Revista do Instistituto de Medicina Tropical São Paulo, v. 31, n. 3, p. 139-145, 1989.

TESH, R. B. Control of zoonotic visceral leishmaniasis: is it time to change strategies? American Journal of Tropical Medicine and Hygiene, v. 52, n. 3, p. 287-292, 1995.

TRAVI, B. L.; TABARES, C. J.; CADENA, H.; OSORIO, Y. Canine visceral leishmaniasis in Colombia: Relationship between clinical and parasitological status and infectivity for sand flies. American Journal of Tropical Medicine and Hygiene, v. 64, p. $119-124,2001$.

TRINCHIERI, G. Interleukin-12 and its role in the generation of TH1 cells. Immunology Today, v. 14, n. 7, p. 335-338, 1993.

TRYPHONAS, L; ZAWIDZKA, Z.; BERNARD, M. A.; JANZEN, E. A. Visceral leishmaniasis in a dog: clinical, hematological and pathological observations. Canadian Journal of Comparative Medicine, v. 41, n. 1, p. 1-12, 1977. 


\section{APROVACÃO}

A Comissão de Ética para Análise de Projetos de Pesquisa - CAPPesq da Diretoria Clínica do Hospital das Clínicas e da Faculdade de Medicina da Universidade de São Paulo, em sessão de 10.11.04, APROVOU o Protocolo de Pesquisa $n^{\circ}$ 706/04, intitulado: "Avaliação da imunidade humoral e celular em cães naturalmente infectados com Leishmania (L.) chagasi e sua correlação com a transmissibilidade para o vetor" apresentado pelo Departamento de PATOLOGIA.

Cabe ao pesquisador elaborar e apresentar à CAPPesq, os relatórios parciais e final sobre a pesquisa (Resolução do Conselho Nacional de Saúde n 196, de 10.10.1996, inciso IX.2, letra "c").

Pesquisador(a) Responsável: Dra. Márcia Dalastra Laurenti Pesquisador(a) Executante: Dra. Daniela Farias Larangeira CAPPesq, 10 de Novembro de 2004.

$$
\text { Ull billo }
$$

PROF. DR. EUCLIDES AYRES DE CASTILHO Presidente da Comissão de Ética para Análise de Projetas de Pesquisa 